\title{
PD-1 overexpression determines the disproportion of circulating Th1/Th17/Treg cells and clinical outcome of multiple myeloma
}

\section{Agata Kosmaczewska ( $\sim$ agata.kosmaczewska@hirszfeld.pl)}

Ludwik Hirszfeld Institute of Immunology and Experimental Therapy https://orcid.org/0000-00023805-9476

\section{Anna Masternak}

District Hospital, Hematology and Oncology Department, Opole

\section{Katarzyna Kosciow}

District Hospital, Hematology and Oncology Department, Opole

\section{Lidia Ciszak}

Ludwik Hirszfeld Institute of Immunology and Experimental Therapy, Wroclaw

\section{Lidia Usnarska-Zubkiewicz}

Wroclaw Medical University, Department of Hematology and Bone Marrow Transplantation

\section{Aleksandra Szteblich}

Ludwik Hirszfeld Institute of Immunology and Experimental Therapy, Wroclaw

\section{Stanislaw Potoczek}

Wroclaw Medical University, Department of Hematology and Bone Marrow Transplantation Irena Frydecka

Ludwik Hirszfeld Institute of Immunology and Experimental Therapy

\section{Research article}

Keywords: multiple myeloma; immune checkpoint; PD-1; PB Th1/Th17/Treg distribution; clinical outcome Posted Date: October 1st, 2019

DOl: https://doi.org/10.21203/rs.2.14312/v1

License: (c) (i) This work is licensed under a Creative Commons Attribution 4.0 International License. Read Full License 


\section{Abstract}

Background The role of particular immune checkpoints in the induction of systemic immunosuppression, which severely complicates the clinical course and prognosis in multiple myeloma (MM), is still unresolved. Only a subset of MM patients treated with checkpoint inhibitors derive benefits, suggesting differential participation of relevant receptors in the inhibitory signaling pathway. This study was undertaken to identify an immune checkpoint playing a key role in systemic T-cell-related immune deficiency in MM in the context of Th1/Th17/Treg cell distribution. Methods We used flow cytometry assay to examine the expression of PD-1, BTLA, and CTLA-4 in peripheral blood (PB) CD4 + , CD4 + CD127 + (Teff), and CD4 + CD127 - (Treg) T cell subsets as well as the balance of Th1/Th17/Treg cells. The study group consisted of 40 untreated (newly diagnosed or relapsed/refractory) myeloma patients in different clinical stages. The obtained results were compared to those observed in 20 healthy controls. Results Among immune checkpoints studied, only PD-1 was expressed on a significantly increased proportion of circulating Teff and Treg cells in MM; we also noted a positive correlation of PD-1 expression with clinical stage. Furthermore, the percentage of PD-1 + Teff cells was correlated with beta2microglobulin serum concentration and shorter overall survival (OS). We also found higher Th17 and Treg compartments in PB irrespectively of tumor stage; however, in some studied subsets, a decrease at stage III was observed. Moreover, PB Th1 deficit (more pronounced in advanced disease) was also observed. Except for the PD-1 + Teff subset, none of the examined cell population was related to OS.Conclusions The study indicates that PD-1 expression on circulating $T$ cell subsets may contribute to the imbalance in PB Th1/Th17/Treg cell distribution and systemic immunosuppression in MM. PD-1 seems to be the only immune checkpoint determining clinical behavior of patients, thereby strengthening the therapeutic potential for inhibitors.

\section{Background}

Multiple myeloma (MM) is an incurable hematologic malignancy characterized by clonal proliferation and accumulation of neoplastic plasma cells producing M-protein in the bone marrow (BM)[1]. Patients with MM exhibit immunosuppressive features that lead to tumor escape, disease growth, and clinical complications, such as bone disease or susceptibility to severe infections [2]. Immune dysfunction in MM results from inhibition of normal plasma cells, but it has also been demonstrated that cellular immunity is impaired. The profound $T$ cell alterations include a rapid loss of effector function and an increase in the abundance of immunosuppressive Tregs within MILs, suggesting a possible role for the immune system in controlling the early growth of transformed cells [2]. Studies on the immune dysregulation in MM showed that, in fact, bone marrow creates an immunologic microenvironment promoting tumor tolerance and immune evasion [3].

A critical role in the development of the immunosuppressive state in $\mathrm{MM}$ has been attributed to the immune checkpoints, such as PD-1, CTLA-4, and BTLA upregulated on T cells isolated from the BM of patients [4]. These molecules play an essential role in the loss of immune surveillance by regulating $T$ cell activation and maintaining peripheral tolerance, and their significance for the development of solid 
tumors and hematologic malignancies has been well documented [5]. Reversing tumor-mediated immune suppression in MM seems to be a critical therapeutic goal in the development of new immunotherapeutic strategies. The introduction of inhibitors targeting the immune checkpoints remarkably shifted the paradigm in the treatment of the tumors [6, 7]. It also represents a very promising approach for certain types of hematologic malignancies including $\operatorname{MM}[6,8,9]$. Remarkably, our knowledge on the role of particular inhibitors in the induction of systemic immunosuppression, which significantly impairs the clinical course and prognosis in MM, is still incomplete. To date, only a subset of MM patients treated with immune checkpoint inhibitors have been shown to derive clinical benefits, primarily after combined therapy [10], suggesting differential participation of appropriate receptors in the inhibitory signaling pathway. Therefore, it is crucial to resolve immunosuppressive mechanisms by identifying the inhibitory pathway dominating in MM patients to achieve their effective control as therapeutic interventions for improvement of the immune responses.

Recently, a role of PD-1 in helper Teff cells' conversion into Treg phenotype has been reported [11]. This observation prompted us to search for possible relationships of particular immune checkpoints' expression on T cells with alterations in Teff and Treg cell distribution in active MM patients as well as the clinical course of the disease. Therefore, we estimated the expression of PD-1, BTLA, and CTLA-4 in $\mathrm{CD}^{+}$(both Teff and Treg) cells isolated from PB of untreated newly diagnosed and refractory MM patients in different clinical stages. In addition, we correlated the values of immune checkpoints' abundance with the frequencies of circulating Th1, Th17, and Treg cells, which are responsible for the maintenance of immune homeostasis and tolerance. The obtained results were compared to those observed in healthy individuals.

\section{Methods}

\section{Samples, cell preparation and patient characteristics}

The study group of patients consisted of 40 newly diagnosed or relapsed/refractory active myeloma patients without treatment for at least 6 months ( 21 female) at different stages of disease progression according to the International Staging System (ISS) [12]. Patients were recruited in the Department of Hematology and Bone Marrow Transplantation at Wroclaw Medical University and the Department of Hematooncology at the District Hospital in Opole $(n=40)$. Patients were diagnosed based on criteria from the International Myeloma Working Group (IMWG) [13]. The control population comprised healthy individuals $(n=20)$ matched for age and sex. Blood samples from all participants were collected after informed consent in accordance with the Declaration of Helsinki and approval by the Institutional Local Research Bioethics Committee at Wroclaw Medical University. The baseline characteristics of the patients are shown in Table 1.

Peripheral blood mononuclear cells (PBMCs) were isolated by buoyant density-gradient centrifugation on Lymphoflot (Biotest, Germany) from $40 \mathrm{ml}$ of freshly drawn peripheral venous blood (PB). All viable cells were frozen and kept in liquid nitrogen until needed for experiments. 


\section{Culture conditions, immunostaining, and flow cytometry}

PBMCs were stained with several combinations of anti-human fluorochrome-conjugated monoclonal antibodies (mAbs) for three-color analysis. Surface staining of CD3, CD4, CD69, BTLA, PD-1, CTLA-4, and CD127 was performed by standard protocols. The following mAbs were used in this procedure: CD3-FITC (Pharmingen, USA), CD4-PerCP (Pharmingen, USA), BTLA-PE (Becton Dickinson, Biosciences, San Diego, USA), PD-1-PE (Pharmingen, USA), CTLA-4-PE (Pharmingen, USA), CD69-PE (Pharmingen, USA), and CD127-FITC (Pharmingen, USA).

Percentages of cytokine-producing T cells (Th1 and Th17) were calculated after stimulation with 25 $\mathrm{ng} / \mathrm{ml}$ phorbol 12-myristate 23-acetate (PMA, Sigma-Aldrich) and $1 \mu \mathrm{g} / \mathrm{ml}$ ionomycin (Ion) (SigmaAldrich) in the presence of $10 \mu \mathrm{g} / \mathrm{ml}$ of brefeldin A (BFA, protein transport inhibitor) (Sigma-Aldrich) for 4 $\mathrm{h}$ at $37^{\circ} \mathrm{C}$ in a humidified atmosphere containing $5 \% \mathrm{CO}_{2}$. Because incubation with PMA triggers internalization and degradation of the CD4 molecule, which would affect the identification of Th1 (phenotyped as $\mathrm{CD} 4^{+} \mathrm{IFN}-\mathrm{\gamma}^{+}$) and Th17 cells (characterized as $\mathrm{CD} 4^{+} \mathrm{IL}-17^{+}$), both subpopulations were identified as $\mathrm{CD}^{+}{ }^{+} \mathrm{CD} 8^{-} \mathrm{IFN}-\gamma^{+}$and $\mathrm{CD} 194^{-} \mathrm{CD} 183^{+} \mathrm{IFN}-\gamma^{+}$as well as $\mathrm{CD} 3^{+} \mathrm{CD} 8^{-} \mathrm{IL}-17^{+}$and $\mathrm{CD} 194^{+} \mathrm{CD} 196^{+} \mathrm{IL}^{-}$ $17^{+}$cells, respectively. Directly after PMA+lon stimulation, PBMCs were surface-stained with respective mAbs as follows: anti-CD3-PerCP (BD Biosciences), anti-CD8-PE (BD Biosciences), anti-CD194-PerCP, antiCD183-PE (BioLegend), and anti-CD196-PE (BioLegend). Then, after fixation and permeabilization with Fixation/Permeabilization Buffer Set (eBioscience), the cells were incubated with anti-IFN- $\gamma-F I T C$ (BD Biosciences) or anti-IL-17-FITC (BioLegend) mAbs for 30 min at room temperature in the dark.

For analysis of the regulatory $T$ cell subpopulations (Tregs), phenotyped as $C D 4^{+} C D 25^{+} C D 127^{-}$, $\mathrm{CD} 4^{+} \mathrm{CD} 25^{\text {high }} \mathrm{CD} 127^{-}, \mathrm{CD} 4^{+} \mathrm{CD} 25^{+} \mathrm{FOXP} 3^{+}, \mathrm{CD} 4^{+} \mathrm{CD} 25^{\text {high }} \mathrm{FOXP}^{+}$, and $\mathrm{CD} 4^{+} \mathrm{CD} 127^{-} \mathrm{FOXP} 3^{+}$cells, $\mathrm{PBMCs}$ were aliquoted into tubes directly after isolation for further staining with the following mAbs: anti-CD4PerCP (BD Biosciences), anti-CD25-FITC (BD Biosciences), anti-CD127-PE (BioLegend), respectively. For intracellular staining, the cells were then fixed and permeabilized with Fixation/Permeabilization Buffer Set (eBioscience) according to the manufacturer's instructions with subsequent incubation with antihuman FOXP3-PE (BD Biosciences) mAbs for 30 min at room temperature in the dark.

Directly after immunostaining, the cells were washed and analyzed by flow cytometry using a FACScan cytometer (Becton Dickinson) equipped with Cell Quest software (BD Biosciences). Appropriate fluorochrome-labeled isotypic controls were used to confirm expression specificity and for gate settings in each case. A total of 30,000 events were recorded for each sample before any electronic gate setting. Data were analyzed by Cell Quest software.

The results were expressed as the proportions of $\mathrm{CD} 3^{+} \mathrm{CD} 4^{+}, \mathrm{CD} 4^{+} \mathrm{CD} 127^{-}$, and $\mathrm{CD} 4^{+} \mathrm{CD} 127^{+}$cells coexpressing BTLA, PD-1, or CTLA-4. The percentages of CD $194^{+} \mathrm{CD} 183^{+}$and $\mathrm{CD} 3^{+} \mathrm{CD} 8^{-}$co-expressing IFN- $\gamma$ as well as $\mathrm{CD} 194^{+} \mathrm{CD} 196^{+}$and $\mathrm{CD} 3^{+} \mathrm{CD} 8^{-}$cells secreting IL-17 were also examined. In addition, we studied the frequencies of CD4+CD25+ cells with the presence of the FOXP3 transcription factor and/or without 
or with low expression of CD127 antigen. The results were also shown as the mean fluorescence intensity (MFI) values of studied molecules and expressed in arbitrary units (AU).

\section{Statistical analysis}

Results are expressed as median values and interquartile ranges. Differences between examined groups were evaluated by using nonparametric tests for paired (Friedman, Wilcoxon) and unpaired (KruskalWallis, Mann-Whitney U) data. Statistical analysis was performed using the package Statistica 7.1. A $p$ value $\leq 0.05$ was considered significant.

\section{Results}

\section{High expression of PD-1 in CD4+ T cell subsets in MM}

It is well established that immune checkpoint receptors play an essential role in the immune surveillance and anti-tumor response [5]. We and others have previously demonstrated the dysregulated expression of CTLA-4, PD-1, and BTLA suppressors in tumors [4, 14-22]. We also reported that CTLA-4 blocking antibody might be a beneficial form of immunotherapy for a proportion of chronic lymphocytic leukemia (CLL) patients depending on the level of CTLA-4 expression on leukemic cells; for those with high CTLA-4 expression, it could be an unfavorable strategy leading to induction of pro-survival signals in CLL cells [18]. We therefore aimed to analyze the involvement of a particular immune checkpoint in the development of systemic T-cell immunosuppression in MM.

In patients, we found a significant increase in PD-1 expressing cells within different PB T cell subsets $\mathrm{CD}^{+}{ }^{+} \mathrm{CD} 4^{+}(15.92 \%$ [11.75\% - 19.25\%], $p=0.025), \mathrm{CD} 4^{+} \mathrm{CD} 127^{+}$(Teff) $(23.53 \%$ [15.84\%-30.05\%], $p=$ $0.025)$, and $C D 4^{+} \mathrm{CD} 127^{-}$(Treg) $(10.62 \%[6.44 \%-13.66 \%], p=0.008)$ - when we compared them to corresponding healthy cells $(12.55 \%$ [8.37\%-15.29\%], 16.87 [10.52\%-21.75\%], and 6.14 [3.90\%-7.62\%], respectively) (Fig. 1a, suppl. 1-2). Regarding tumor stage, we observed no marked differences among the patients with respect to studied cell subpopulations (Table 2).

Analysis of PD- 1 fluorescence intensity in $\mathrm{CD} 4^{+}$and $\mathrm{CD} 4^{+} \mathrm{CD} 127^{+}$Teff cells revealed no statistically significant differences between patients and healthy controls (Tables 3 and 4). In contrast, we noted diminished PD-1 amounts in MM CD $4^{+}$CD 127- Treg cells (Table 3), more pronounced in stage I/II of the disease when compared to healthy individuals (Table 4).

Although the median PD-1 intensity in Tregs from patients at stage III remained at a comparable level to that found in healthy Tregs, it was significantly up-regulated when compared to patients at stage I/II (Table 4).

\section{Unaffected frequency of BTLA ${ }^{+} \mathrm{T}$ cells in MM patients}


In contrast, we found no significant differences in the percentages of $\mathrm{BTLA}^{+}$cells within $\mathrm{CD} 3^{+} \mathrm{CD} 4^{+}$, $\mathrm{CD} 4^{+} \mathrm{CD} 127^{+}$Teff and CD4 ${ }^{+} \mathrm{CD} 127^{-}$Treg cells between patients (27.20\% [21.61\%-55.72\%]; $42.62 \%$ [22.93\%-67.43\%]); 5.30\% [2.00\%-9.64\%], respectively) and healthy individuals (23.85\% [17.04\%-40.16\%]; $32.50 \%$ [20.75\%-54.43\%]; 2.87\% [1.85\%-3.40\%], respectively) (Fig. 1b, Additional file 1 and 2).

Also, we did not find any differences in BTLA expression in CD $4^{+} \mathrm{T}$ cells, CD $4^{+} \mathrm{CD} 127^{+}$Teff and CD $4^{+}$CD $127^{-}$Treg cells among patients regarding tumor stage (Tables 2 and 4 ).

In contrast, a decrease in the MFI values of BTLA in the MM CD4 $4^{+}$and $\mathrm{CD} 4^{+} \mathrm{CD} 127^{+}$Teff cell subsets and no significant difference in BTLA levels in $\mathrm{CD} 4^{+} \mathrm{CD} 127^{-}$Treg cells compared to controls were seen (Table $3)$.

\section{Unaffected frequency of CTLA-4 ${ }^{+} \mathrm{T}$ cells in MM patients}

The proportions of CTLA-4-expressing $\mathrm{CD} 3^{+} \mathrm{CD} 4^{+}, \mathrm{CD} 4^{+} \mathrm{CD} 127^{+}$Teff and $\mathrm{CD} 4^{+} \mathrm{CD} 127^{-}$Treg cells did not significantly differ between patients (1.51\% [0.89\% - 2.51\%]; 3.28\% [1.75\% - 6.00\%]; $1.82 \%$ [0.75\% - 2.32\%], respectively) and controls (1.27\% [0.78\% - 2.00\%]; 3.55\% [1.64\% - 4.22\%]; 1.14\% [0.56\% - 1.37\%], respectively) (Fig. 1c, suppl. 1-2). Similarly to BTLA, CTLA-4 expression in the examined T cells did not differ among patients regarding MM stage (Tables 2 and 4).

Of note, the MFI values of CTLA-4 on $\mathrm{CD} 4^{+} \mathrm{CD} 127^{+}$Teff and $\mathrm{CD} 4^{+} \mathrm{CD} 127^{-}$Tregs were lower in MM compared to corresponding healthy cells (Table 3 ).

Taken together, the results show that PD-1 is the only immune $T$ cell inhibitor significantly increased among PB CD4+ T cell subsets of MM patients.

\section{PD-1 determines clinical course of MM}

There is growing body of evidence, including ours, that alterations in the immune checkpoints' expression in T cells affect the clinical outcome of cancer $[4,14,16,18-22]$. Therefore, we wanted to find out whether the dysregulated expression of $\mathrm{T}$ cell inhibitors in $\mathrm{MM}$ might be associated with clinicopathologic features, such as albumin and beta2-microglobulin level, myeloma isotype, PLC numbers in the BM, light chain, renal function, and tumor stage.

Some associations were found between both the proportions of the CD $4^{+} \mathrm{CD} 127^{+} \mathrm{PD}-1^{+}$cells or tumor clinical stage and the serum levels of beta2-microglobulin (Fig. 2a and c). Although quantitative analysis revealed no significant differences in PD- 1 amounts in the $C D 4^{+} \mathrm{CD} 127^{+}$Teff subset between patients and healthy controls, worthy of note was a correlation of borderline significance of PD-1 levels in these cells with tumor stage (Fig. 2d). Similarly, we observed that the PD- 1 intensity values in CD $4^{+}$CD $127^{-}$Treg cells were also correlated with tumor stage (Fig. 2e). In contrast, there was no correlation of PD-1 expression with other indices of severe disease. 
We observed no significant association of BTLA and CTLA-4 expression in CD4+, CD4+CD127+ Teff, and CD4+CD127- Treg cells with any of the clinicopathological indices studied (not shown).

\section{PD-1 rather than BTLA or CTLA-4 affects MM patient survival}

We also analyzed our patient cohort regarding the possible dependence of the patients' overall survival (OS) on the studied immune checkpoint receptors. We stratified for low and high expression of each factor according to median split.

In the group of studied patients, we did not find any association between PD $-1^{+}, \mathrm{BTLA}^{+}$, and CTLA-4 ${ }^{+}$cell frequencies in the whole PB CD4+ T cell population and patients survival (Additional file 3a-c). However, further analysis of $\mathrm{CD} 4^{+} \mathrm{CD} 127^{+}$Teff and $\mathrm{CD} 4^{+} \mathrm{CD} 127^{-}$Treg subsets revealed that patients with high abundance of PB PD-1 $1^{+}$Teff cells have worse survival than patients with a low percentage of these cells (Fig. 3a). In contrast, the frequency of PD-1 ${ }^{+}$Tregs (Fig. 3b) as well as BTLA ${ }^{+}$and CTLA-4 ${ }^{+}$cells within circulating $\mathrm{CD} 4^{+} \mathrm{CD} 127^{+}$Teff and CD $4^{+} \mathrm{CD} 127^{-}$Treg cells did not influence patients' survival (Additional file $3 d-g)$.

The above results indicate clear involvement of PD-1 rather than the other inhibitory receptors in MM clinical outcome.

\section{Activated phenotype of PB CD4+ T cells affects MM clinical outcome}

In the light of demonstration that the expression of immune checkpoints is induced upon cell stimulation in order to suppress the ongoing immune response, we analyzed the state of systemic activation of MM CD4+ T cells.

As expected, in MM patients, the median proportion of circulating $\mathrm{CD} 4^{+} \mathrm{CD} 69^{+} \mathrm{T}$ cells were significantly higher than in healthy controls $(0.58 \%$ [0.25\% - 0.96\%] vs. 0.33\% [0.22\% - 0.44\%] $p=0.01)$, primarily at stage III (Table 2). In consequence, the abundance of activated PB CD4 ${ }^{+} \mathrm{T}$ cells was correlated with MM stage (Fig. 2b). In addition, a higher proportion of $\mathrm{MM} \mathrm{CD} 4^{+} \mathrm{CD} 69^{+} \mathrm{T}$ cells in PB showed some association with poor survival (Fig. 3c).

The in vitro stimulation revealed that patients' cultured CD4+ T cells exhibited a lower proportion of CD69+ cells than corresponding healthy cells (44.29\% [26.22\% - 54.72\%] vs. 55.73\% [53.00\% - 73.16\%], $p$ $=0.044$ ) under the same stimulation conditions.

Regarding MFI values, there was no marked difference in the levels of CD69 expression in either freshly isolated or in vitro stimulated T cells between the groups (Tables 3 and 4).

This part of the data shows that MM CD4+ T cells are maximally activated in vivo most likely by myeloma antigens, thereby supporting strengthened inhibition.

\section{Lower abundance of Th1 cells in PB of MM patients}


Recently, the involvement of PD-1 expression in conversion of conventional T cells, primarily Th1, into regulatory $T$ cells has been demonstrated [11]. Therefore, we wanted to verify whether overexpression of PD-1 as the only inhibitor dysregulated in the different PB CD4+ T cell subtypes might contribute to peripheral imbalance in Th1/Th17/Treg distribution in our cohort of patients.

Th1 cells were detected as CD194 CD $183^{+}$IFN- $\gamma^{+}$and CD $3^{+}$CD8 ${ }^{-1 F N}-\gamma^{+}$cells. In the MM group, we observed significantly diminished proportions of Th1 cells presented with respective phenotypes compared to corresponding cells from healthy donors (3.45\% [2.22\% - 5.80\%] vs. 8.77\% [5.13\% - 9.71\%], $p$ $=0.002$ and $4.49 \%[3.22 \%-7.00 \%]$ vs. $9.00 \%$ [7.66\% - 10.07\%], $p=0.0004$, respectively) (Fig. 4a).

Although we did not find any significant differences in the abundance of Th1 cells in PB between patients at different stages of the disease, the largest CD3+CD8-IFN- $\gamma+$ cell deficit was observed in the most advanced MM when compared to the control group only (Table 5).

Also, we found markedly lower values of IFN-y fluorescence intensity in the respective Th1 populations than those seen in corresponding control cells (52.49 [26.23-79.14] vs. 83.24 [64-97-102.43], $p=0.003$ and 31.86 [20.72-37.10] vs. 58.79 [36.41-69.87], $p=0.01$, respectively).

\section{Elevated Th17 cells in PB of MM patients}

Simultaneously, we assessed the number of PB Th17 cells, which were identified as CD $194^{+}$CD $196^{+} I L-17^{+}$ and $\mathrm{CD} 3^{+} \mathrm{CD} 8 \mathrm{IL}-17^{+}$. In patients, the median frequencies of PB Th17 cells were significantly higher than in healthy controls $(0.56 \%[0.30 \%-0.83 \%]$ vs. $0.36 \%[0.26 \%-0.45 \%], p=0.042$ and $0.51 \%[0.25 \%-0.65 \%]$ vs. $0.32 \%[0.22 \%-0.45 \%], p=0.021$, respectively) (Fig. $4 b$ ).

There was no difference in the phenotyped Th17 cell abundance between patients' groups characterized by clinical stage (Table 5). However, we observed that subjects at stage $\mathrm{I} / \mathrm{II}$ exhibited markedly increased proportions of $\mathrm{CD}^{+}{ }^{+} \mathrm{CD} 8^{-} \mathrm{IL}-17^{+}$cells compared to controls only; patients at stage III demonstrated normal frequency of these cells, however, some trend toward a higher level was seen as well (Table 5).

The MFI values of IL-17 in respective Th17 subpopulations were lower or comparable to those seen in controls (43.14 [38.55-52.85] vs. 63.57 [47.48-78.94], $p=0.002$ and 23.39 [13.14-39.00] vs. 21.98 [16.3752.11], $p>0.05$, respectively).

\section{Elevated Treg cells in PB of MM patients}

We next determined Treg cells as $\mathrm{CD} 4^{+} \mathrm{CD} 25^{+} \mathrm{CD} 127^{-}, \mathrm{CD} 4^{+} \mathrm{CD} 25^{\text {high }} \mathrm{CD} 127^{-}, \mathrm{CD} 4^{+} \mathrm{CD} 25^{+} \mathrm{FOXP} 3^{+}$, $\mathrm{CD} 4^{+} \mathrm{CD} 25^{++} \mathrm{FOXP3}{ }^{+}$, and $\mathrm{CD} 4^{+} \mathrm{FOXP} 3^{+} \mathrm{CD} 127^{-}$cells. The median percentages of studied Treg subsets were significantly higher in MM patients in comparison to the healthy controls (Table 6, Fig. 5a and b).

We found no differences between Treg proportions in PB of MM patients at the different stages of the disease, except for $\mathrm{CD} 4^{+} \mathrm{CD} 25^{+} \mathrm{FOXP} 3^{+}$and $\mathrm{CD} 4^{+} \mathrm{FOXP3}{ }^{+} \mathrm{CD} 127^{-}$cell subsets, which were significantly 
lower at stage III of $\mathrm{MM}$ compared to the values observed at stage $\mathrm{I} / \mathrm{Il}$, although remaining still increased compared to those seen in controls (Table 5).

Altogether, our data suggest that MM development is related to a clear imbalance in PB Th1, Th17, and Treg cells.

\section{Correlation of the frequencies of PB Treg cells with prognostic factors}

Given the demonstrated correlation of T-cell immunosuppression with tumor progression, we sought to evaluate possible relationships between PB Th1/Th17/Treg alteration and laboratory or clinical signs of MM progression. We found no associations of Th1 and Th17 with the level of albumin or beta2microglobulin, type of Ig, light chain, renal function or tumor progression (not shown).

In contrast, among examined subtypes of PB Treg cells, the abundance of $\mathrm{CD} 4^{+} \mathrm{CD} 25^{+} \mathrm{CD} 127^{-}$and $\mathrm{CD} 4^{+} \mathrm{FOXP} 3^{+} \mathrm{CD} 127^{-}$cells was observed to negatively correlate with some clinicopathological features (Fig. 2f-h). In particular, $C D 4^{+} \mathrm{CD} 25^{+} \mathrm{CD} 127^{-}$cells were associated with $\beta 2$-microglobulin level as well as MM stage (Fig. $2 f$ and $g$ ); however, the latter correlation was of borderline significance only. Similarly, we observed that the frequency of $\mathrm{CD} 4^{+} \mathrm{FOXP} 3^{+} \mathrm{CD} 127^{-}$cells was associated with tumor stage as well (Fig. $2 \mathrm{~h}$ ). There was no other correlation of Treg frequency with albumin concentration, type of Ig, light chain or renal function (not shown).

\section{No association of PB Th1, Th17, and Treg cell abundance with patient survival}

None of the phenotyped PB Th1, Th17 or Treg subpopulations contributed to patients' overall survival (Additional file 4).

Taking the evidence together, progression of $\mathrm{MM}$ is accompanied by dysregulated peripheral abundance of the CD4+ T cell subsets involved in the tumor responses, which could not affect patient survival.

\section{Discussion}

Recent clinical trials demonstrated that a substantial proportion of MM patients remained without any response after administration of immune checkpoint inhibitors [8]. Therefore, it still remains to be defined which inhibitory pathway is of importance in mediating development of the immunosuppressive state in MM. We cannot exclude that involvement of particular receptors in the inhibitory pathway is different in certain patients or a contribution of other receptors to T-cell immune deficiency in non-responding MM patients may occur. Therefore, there is a need for identification of biomarkers predicting responses to the blockade of various checkpoints depending on their expression on T cells in MM patients.

The results of the this study support a decisive role of PD-1 in the development of systemic T cell immune suppression in myeloma. We show that among the studied immune checkpoints, only PD-1 expression has been found in MM on markedly higher proportions of the PB Teff and Treg cells. Furthermore, PD-1 is the only receptor correlated with poor clinical outcome determined by disease stage 
and overall survival. Together this may indicate the limited significance of BTLA and CTLA-4 for MM immunopathology and emphasizes the superior role of PD-1. Thus, we hypothesize that myeloma growth disrupts the expression of immune checkpoints not only in the BM environment, but also in the periphery, thereby supporting the tumor-derived systemic immune suppression. This observation is consistent with the report of Rosenblatt et al. [4], who observed increased PD-1 expression on PB CD4+ T cells in myeloma patients with advanced active disease as a result of chronic antigen stimulation, thereby contributing to tumor-induced suppression of T cell responses. A reduction of PD-1 expression on circulating $T$ cells in patients who achieve a minimal disease state following high-dose chemotherapy strongly confirms an association of PD-1 expression with the tumor antigen stimulation in vivo. Our finding of PD-1 correlation with myeloma clinical progression and tumor burden seems to strengthen the above observation.

On the other hand, many reports have demonstrated that high antigen load and persistent $\mathrm{T}$ cell stimulation in the tumor microenvironment drive the functional exhaustion of $\mathrm{CD} 4^{+}$and $\mathrm{CD} 8^{+} \mathrm{T}$ cells, which is correlated with the expression of inhibitors, such as PD-1, TIM-3, or CTLA-4 [19-22]. In the course of $\mathrm{MM}, \mathrm{T}$ cell exhaustion occurs predominantly in the BM, while PB T cells might also exert abrogated function, albeit to a minor extent $[5,21]$. In fact, we observed increased frequencies of in vivo stimulated $\mathrm{MM} \mathrm{CD} 69^{+} \mathrm{T}$ helper cells with the lower potential to respond to further in vitro polyclonal stimulation. This fact together with higher abundance of PD- 1 on circulating CD $4^{+}$T cells seem to confirm their in vivo stimulated as well as exhausted phenotype in the cohort of untreated active MM patients [23].

However, PD-1 dysregulation in circulating different MM T cell subtypes suggests its leading role in Teff exhaustion, but also in Treg suppressor function. In fact, herein we show that both PD-1 $1^{+}$Teff and PD-1 $1^{+}$ Treg cells remained at heightened frequencies in PB irrespectively of tumor stage. At a semiquantitative level, we noted, however, PD-1 increase in Tregs in patients at stage III, thus suggesting a major role for $\mathrm{PD}-1^{+}$Tregs in the systemic immunosuppression development in MM, primarily in the most advanced disease. This is in accordance with the demonstration that PD-1 enhances regulatory properties in Tregs and confirms the former study reporting that the main population participating in immune deficiency during tumor progression is the PD- $1^{+}$Treg subset $[24,25]$. The wide expression of PD-1L on neoplastic plasma cells and dendritic cells (DCs) might facilitate interaction with PD-1 on the marrow infiltrating lymphocytes (MILs), and strongly restricts anti-tumor T cell responses within the BM microenvironment, thereby allowing for the tumor escape $[25,26]$. Our finding of PD-1 overexpression on PB different T cell subtypes indicates that the PD-1/PD-L1 axis likely is of great importance in MM-related systemic immune deficiency, thereby strengthening the therapeutic potential for PD-1 inhibitors.

Recently, there is a growing body of evidence that PD-1 might disrupt the balance of conventional/regulatory $T$ cells in several immune systems $[11,27,28]$. We have observed that dysregulated expression of the immune checkpoints in the examined cohort of patients is accompanied by alterations in the frequencies of Th1, Th17, and Treg cell subsets in the periphery. In particular, we noted a deficiency in the Th1 cell population when considering the impaired capability of Teff cells for 
IFN-y secretion, which confirms recent observations [29, 30]. It may, at least in part, reflect the impaired responsiveness of helper T cells to persistent in vivo stimulation as a consequence of cell exhaustion, indicating that (similarly to $\mathrm{CD} 8^{+}$population) $\mathrm{CD} 4+\mathrm{T}$ cells in MM may also be dysfunctional [16]. One of the mechanisms for peripheral Th1 deficit in MM may also be related to constrained Th1 differentiation as a result of the high serum concentration of Th17 cytokines [3]. Also, the enforced recruitment of Th1 effector cells from PB into the BM is a rationale for eliciting an anti-tumor response at the tumor site [31]. This process is managed by Th17 cells accumulating in high abundance in the myeloma BM [32, 33]. PD1 involvement in the conversion of T helper cells, primarily Th1, into peripheral Treg cells cannot be excluded as well [11]. The latter mechanism of Th1 loss seems to be functional also in the experimental system studied, since we found that PB Th1 down-regulation during the course of MM is associated with the expansion of circulating Tregs. This confirms the reports on the PB Treg increase during the course of MM [34-37]. Although we observed a decrease in some Treg subsets (such as $\mathrm{CD} 4^{+} \mathrm{CD} 25^{+} \mathrm{FOXP} 3^{+}$and $\mathrm{CD} 4^{+} \mathrm{CD} 127-\mathrm{FOXP}^{+}$cell populations) at stage III, their values remained still expanded in the periphery irrespectively of tumor stage. What is more important, we found that enlarged proportions of MM Tregs exhibited PD-1, which indicates reinforced regulatory function at every stage of MM. At this point of the study, we cannot completely explain the decrease in 2 out of 5 examined Treg phenotypes during MM progression. However, infiltration of the BM by circulating Tregs should be taken into consideration, as these cells acquire chemokine receptors promoting trafficking to the tumor site. In fact, Tregs accumulate in the BM primarily in the most progressive disease, whereby they create a highly immunosuppressive microenvironment in the BM and support tumor growth $[5,38,39]$.

In the current study, we also confirm the demonstration of the significantly higher level of proinflammatory Th17 cells in the PB of MM patients [40]. In the light of the contradictory studies, the role of Th17 in tumor development still remains unresolved [36, 41]. Th17 increase in MM is in accordance with the observation that tumorigenesis is closely related to chronic infection and inflammation [36, 40-43]. Although several mechanisms may be responsible for Th17 peripheral expansion in myeloma, the wider context including PB Th17 differentiation and cell conversion, but also alterations in Th17 cell redistribution between PB and BM, should be considered $[36,44]$. The latter suggestion is supported by the demonstration that Th17 (similarly to Treg cells) are strongly positive for homing molecules such as CCR6, CCR7, CXCR4, CCR5 associated with cell migration and trafficking [43]. Furthermore, the malignant BM microenvironment in MM supports Th17 differentiation and accumulation [40, 41, 43]. High amounts of IL-1 $\beta$, IL-6, IL-21, IL-23 in the presence of TGF- $\beta$ might induce Th17 polarization also in the periphery, although to a minor extent as compared to the BM $[3,45]$. In consequence, myeloma BM becomes a reservoir of Th17 cells, thereby migrating into the PB and reinforcing the Th17 cell compartment [40].

Remarkably, among mechanisms involved in Th17 differentiation a role for PD-1 has recently been postulated in a mechanism similar to Th1 conversion into Tregs [27]. However, further studies did not confirm the above suggestion [28]. Taking into account that tumor-derived Th17 cells had minimal or no expression of PD-1 [32,43], the significance of PD-1 expression on Th17 cells in Treg induction should be considered with caution. Consistently with this observation, we found no correlation between PD-1 or

Page $11 / 28$ 
other checkpoint molecule expression on Teff or Treg cells and PB Th17 distribution in MM, suggesting highly autonomous Th17 expansion in MM.

Given the demonstrated substantial Th17 increase in the periphery, we did not observe its correlation with tumor stage, as was previously reported [41]. Furthermore, we noted normalization of $\mathrm{CD}^{+} \mathrm{CD} 8 \mathrm{IL}-17^{+}$cell frequencies in PB at stage III of MM, whereas in patients at stage $\mathrm{l} / \mathrm{II}$ this subset remained significantly increased compared to healthy controls. Actually, in the most progressive MM, Th17 cells may migrate not only to the tumor site, but they also infiltrate the bones, leading to a lytic disaster. Based on the demonstration of Th17 capacity to activate osteoclasts and osteolysis, the BM Th17 accumulation is regarded as a predictor of bone lytic disease, thereby characterizing the advanced disease [40]. In the light of the above notion and previous report showing a correlation of PB Th17 abundance with bad prognostic factors [41], the results of the present study suggest pro-tumor rather than anti-tumor activity of the Th17 subset in MM.

\section{Conclusions}

We conclude that myeloma development occurs together with profound peripheral dysregulation of Th1/Th17/Treg cell distribution; an enlarged PB Th17 subset is accompanied by a high Treg/Th1 ratio, which may reflect systemic T-cell-mediated immune suppression in MM complicating clinical behavior. A tendency to peripheral Th1, Th17, and Treg subset decrease observed in the most advanced disease may suggest selective infiltration of the malignant BM by $T$ cells playing a key role in the tumor immunity. Our finding that PD-1 overexpression in circulating T cells may determine the disproportion of Th1, Th17, and Treg cells as well as the clinical outcome of myeloma patients makes it easier to refine a cellular target for an immunotherapy approach based on inhibitors.

\section{Abbreviations}

PD-1: Programmed death receptor 1; Th: Helper T cell; MM: Multiple myeloma; BTLA: B- and T-lymphocyte attenuator; CTLA-4: Cytotoxic T-lymphocyte antigen-4; PB: Peripheral blood; Teff: Effector T cell; Treg: Regulatory T cell; OS: Overall survival; ISS: International Staging System; PBMC: Peripheral blood mononuclear cell; CD: Cluster of differentiation; PMA: Phorbol 12-myristate 23-acetate; BFA: Brefeldin A; IFN: Interferon; IL: Interleukin; FOXP3: Forkhead box P3; BM: Bone marrow; TIM: T-cell immunoglobulin and mucin-domain containing ; PD-1L: PD-1 ligand; DC: Dendritic cell; MIL: Marrow infiltrating lymphocyte; CCR: Chemokine receptor; CXCR: CXC chemokine receptor; TGF: Transforming growth factor.

\section{Declarations}


Not applicable.

\section{Funding}

This study was supported by a grant from the Wroclaw Centre of Biotechnology, the Leading National Research Centre (KNOW) program for the years 2014-2018 (grant no. 132/2017/KNOW/IITD).

\section{Availability of data and materials}

The datasets used and analyzed during the current study are all available from the corresponding author.

\section{Authors' contributions}

Conception and design of the experiments: AK. Collection of samples: AM, KK, LUZ and SP. Performance of the experiments: AK, LC, AM, KK and AS. Analysis of the data: AK, LC, AM and KK. Contribution of reagents/materials/analysis tools: $L C, A M, K K, A S$ and LUZ. Writing of the paper: AK, AM and KK. Editing of the paper: LC and AK. Supervision of the study: IF and AK. All authors read and approved the final manuscript.

\section{Ethics approval and consent to participate}

This study was approved by the ethics committee of Wroclaw Medical University.

\section{Consent for publication}

Not applicable.

\section{Competing interests}

The authors declare that they have no competing interests.

\section{References}

1. Kyle RA, Rajkumar SV. Criteria for diagnosis, staging, risk stratification and response assessment of multiple myeloma. Leukemia. 2009;23:3-9.

2. Pratt G, Goodyear O, Moss P. Immunodeficiency and immunotherapy in multiple myeloma. $\mathrm{Br} \mathrm{J}$ Haematol. 2007;138:563-579.

3. Prabhala RH, Pelluru D, Fulciniti M, Prabhala HK, Nanjappa P, Song W, et al. Elevated IL-17 produced by Th17 cells promotes myeloma cell growth and inhibits immune function in multiple myeloma. Blood. 2010;115:5385-5392.

4. Rosenblatt J, Glotzbecker B, Mill H, et al. PD-1 blockade by CT-011, anti-PD-1 antibody, enhances ex vivo T-cell responses to autologous dendritic cell/myeloma fusion vaccine. J Immunother. 2011;34:409-418. 
5. Zeller-Rieser C, Thangavadivel S, Biedermann R, Brunner A, Stoitzner P, Willenbacher E, et al. T cells in multiple myeloma display features of exhaustion and senescence at the tumor site. J Hematol Oncol. 2016;9:116.

6. Hallett WHD, Jing W, Drobyski WR, Johnson BD. Immunosuppressive effect of multiple myeloma are overcome by PD-L1 blockade. Biol Blood Marrow Transplant. 2011;17:1133-1145.

7. Xing J, Lu G, Liu GQ, Xu M, Zhao X, Han, F, et al. Imbalance of Treg/Th17 in bone marrow of patients with multiple myeloma. Zhongguo Shi Yan Xue Ye Xue Za Zhi. 2014;22:1321-1325.

8. Atanackovic D, Luetkens T. Biomarkers for checkpoints inhibition in hematologic malignancies. Semin Cancer Biol. 2018;52:198-206.

9. Kearl TJ, Jing W, Gershan JA, Johnson BD. Programmed Death Receptor-1/Programmed Death Receptor Ligand-1 blockade after transient lymphodepletion to treat myeloma. J Immunol. 2013;190:5620-5628.

10. Wolchok JD, et al. Nivolumab plus ipilimumab in advanced melanoma. N Engl J Med. 2013;369:122133.

11. Amarnath S, Mangus CW, Wang JCM, Wei F, He A, Kapoor V, et al. The PDL-PD-1 axis converts human Th1 cells into regulatory T cells. Sci Transl Med. 2011;3:111ra120.

12. Greipp PR, San Miguel J, Durie BG., Crowley JJ, Barlogie B, Blade J et al. International staging system for multiple myeloma. J Clin Oncol. 2005;23:3412-3420.

13. Rajkumar SV, Dimopoulos MA, Palumbo A, Blade J, Merlini G, Mateos MV, et al. Internationaal Myeloma Working Group updated criteria for the diagnosis of multiple myeloma. The Lancet Oncol. 2014;15:e538-e548.

14. Kosmaczewska A, Frydecka I, Bocko D, Ciszak L, Teodorowska R. Correlation of blood lymphocyte CTLA-4 (CD152) induction in Hodgkin's disease with proliferative activity, interleukin 2 and interferongamma production. Br J Haematol. 2002;118:202-209.

15. Frydecka I, Kosmaczewska A, Bocko D, Ciszak L, Wolowiec D, Kuliczkowski K, et al. Alterations of the expression of T-cell related costimulatory CD28 and down regulatory CD152 (CTLA-4) molecules in patients with B-cell chronic lymphocytic leukemia. Br J Cancer. 2014;90:2042-2048.

16. Kosmaczewska A, Ciszak L, Suwalska K, Wolowiec D, Frydecka I. CTLA-4 overexpression in CD19+CD5+ cells correlates with the level of cell cycle regulators and disease progression in B-CLL patients. Leukemia. 2005;19:301-304.

17. Ciszak L, Frydecka I, Wolowiec D, Szteblich A, Kosmaczewska A. CTLA-4 affects expression of key cell cycle regulators of G0/G1 phase in neoplastic lymphocytes from patients with chronic lymphocytic leukemia. Clin Exp Med. 2016;16:317-332.

18. Ciszak L, Frydecka I, Wolowiec D, Szteblich A, Kosmaczewska A. Patients with chronic lymphocytic leukemia (CLL) differ in the pattern of CTLA-4 expression on CLL cells: the possible implications for immunotherapy with CTLA-4 blocking antibody. Tumour Biol. 2016;37:4143-4157.

19. Fourcade J, Sun Z, Pagliano O, Guillaume P, Luescher IF, Sander C, et al. CD8+ T cells specific for tumor antigens can be rendered dysfunctional by the tumor microenvironment through upregulation 
of the inhibitory receptors BTLA and PD-1. Cancer Res. 2011;72:887-896.

20. Thommen DS, Schreiner J, Muller P, Herzig P, Roller A, Belousov A, et al. Progression of lung cancer is associated with increased dysfunction of $T$ cells defined by coexpression of multiple inhibitory receptors. Cancer Immunol Res. 2015;3:1344-1355.

21. Tan J, Chen S, Huang J, Chen Y, Yang L, Wang C, et al. Increased exhausted CD8 ${ }^{+}$T cells with programmed death-1, T-cell immunoglobulin and mucin-domain-containing-3 phenotype in patients with multiple myeloma. Asia Pac J Clin Oncol. 2018;14:e266-e274.

22. Arai Y, Saito H, Ikeguchi M. Upregulation of TIM-3 and PD-1 on CD4+ and CD8+ T cells associated with dysfunction of cell-mediated immunity after colorectal cancer operation. Yonago Acta Med. 2012;55:1-9.

23. Nan XP, Zhang Y, Yu HT, Li Y, Sun RL, Wang JP, et al. Circulating CD4+CD25high regulatory T cells and expression of PD-1 and BTLA on CD4+ T cells in patients with chronic hepatitis B virus infection. Viral Immunol. 2010;23:63-70.

24. Park HJ, Park JS, Jeong YH, Son J, Ban YH, Lee BH, et al. PD-1 upregulated on regulatory T cells during chronic virus infection enhances the suppression of CD8+ T cell immune response via the interaction with PD-L1 expressed on CD8+ T cells. J Immunol. 2015;194:5801-5811.

25. Sponaas AM, Moharrami NN, Feyzi E, Standal T, Rustad EH, Waage A, et al. PDL1 expression on plasma and dendritic cells in myeloma bone marrow suggests benefit of targeted anti PD-1-PDL1 therapy. PLOS One 2015;10(10):e0139867.

26. Ishibashi M, Tamura H, Sunakawa M, Kondo-Onodera A, Okuyama N, Hamada Y, et al. Myeloma drug resistance induced by binding of myeloma B7-H1 (PD-L1) to PD-1. Cancer Immunol Res. 2016;4:779788.

27. Chen X, Fosco D, Kline DE, Meng L, Nishi S, Savage PA, et al. PD-1 regulates extrathymic regulatory Tcell differentiation. Eur J Immunol. 2014;44:2603-16.

28. Ellestad KK, Thangavelu G, Ewen CL, Boon L, Anderson CC. PD-1 is not required for natural or peripheral induced regulatory $\mathrm{T}$ cells: severe autoimmunity despite normal production of regulatory $\mathrm{T}$ cells. Eur J Immunol. 2014;44:3560-3572.

29. Frassanito MA, Cusmai A, Dammacco F. Deregulated cytokine network and defective Th1 immune response in multiple myeloma. Clin Exp Immunol. 2001;125:190-197.

30. Sharma A, Khan R, Joshi S, Kumar L, Sharma M. Dysregulation in T helper 1/T helper 2 cytokine ratios in patients with multiple myeloma. Leuk Lymphoma. 2010;51: 920-927.

31. Hong S, Qian J, Yang J, Li H, Kwak LW, Yi Q. Roles of idiotype-specific T cells in myeloma cell growth and survival: Th1 and CTL cells are tumoricidal while Th2 cells promote tumor growth. Cancer Res. 2008;68:8456-8464.

32. Kryczek I, Banerjee M, Cheng P, Vatan L, Szeliga W, Wei S, et al. Phenotype, distribution, generation, and functional and clinical relevance of Th17 cells in the human tumor environments. Blood. 2009;114:1141-1149. 
33. Zhong AY, Pan X, Shi MH. Expression of PD-1 by CD4+CD25+CD127low Treg cells in the peripheral blood of lung cancer patients. Onco Targets Ther. 2015;8:1831-1833.

34. Braga WMT, Atanackovic D, Colleoni GWB. The role of regulatory T cells and Th17 cells in multiple myeloma. Clin Dev Immunol. 2012; article 293479.

35. Bryant C, Suen H, Brown R, Yang S, Favaloro J, Aklilu E, et al. Long-term survival in multiple myeloma is associated with a distinct immunological profile, which includes proliferative cytotoxic T-cell clones and a favorable Treg/Th17. Blood Cancer J. 2013;3:e148.

36. Giannopoulos K, Kaminska W, Hus I, Dmoszynska A. The frequency of T regulatory cells modulates the survival of multiple myeloma patients: detailed characterisation of immune status in multiple myeloma. Br J Cancer. 2012;106:546-552.

37. Raja KRM, Rihova L, Zahradova L, Klincova M, Penka M, Hajek R. Increased T regulatory cells are associated with adverse clinical features and predict progression in multiple myeloma. PLOS One. 2012;7:e47077.

38. Braga WMT, da Silva BR, de Carvalho AC, Maekawa YH, Bortoluzzo AB, Rizzatti EG, et al. FOXP3 and CTLA4 overexpression in multiple myeloma bone marrow as a sign of accumulation of CD4+ T regulatory cells. Cancer Immunol Immunother. 2014;63:1189-1197.

39. Favaloro J, Brown R, Aklilu E, Yang S, Suen H, Hart D, et al. Myeloma skews regulatory $T$ and proinflammatory $T$ helper 17 cell balance in favor of a suppressive state. Leuk Lymphoma. 2014;55:1090-1098.

40. Noonan K, Marchionni L, Anderson J, Pardoll D, Roodman GD, Borrello I. A novel role of IL-17producing lymphocytes in mediating lytic bone disease in multiple myeloma. Blood. 2010;116:35543563.

41. Shen CJ, Yuan ZH, Liu YX, Hu GY. Increased numbers of T helper 17 cells and the correlation with clinicopathological characteristics in multiple myeloma. J Int Med Res. 2012;40:556-564.

42. Dhodapkar KM, Barbuto S, Matthews P, Kukreja A, Mazumder A, Vesole D, et al. Dendritic cells mediate the induction of polyfunctional human IL17-producing cells (Th17-1 cells) enriched in the bone marrow of patients with myeloma. Blood. 2008;112:2878-2885.

43. Su X, Ye J, Hsueh EC, Zhang Y, Hoft DF, Peng G. Tumor microenvironments direct the recruitment and expansion of human Th17 cells. J Immunol. 2010;184:1630-1641.

44. Muranski P and Restifo NP. Essentials of Th17 cell commitment and plasticity. Blood. 2013;121:2402-2414.

45. Feng P, Yan R, Dai X, Xie X, Wen H, Yang S. The alteration and clinical significance of Th1/Th2/Th17/Treg cells in patients with multiple myeloma. Inflammation. 2015;38:705-709.

\section{Tables}

Table 1 Patient demographics and characteristics 


\begin{tabular}{|c|c|c|c|}
\hline Characteristic & $\begin{array}{c}\text { Newly diagnosed } \\
\text { MM }\end{array}$ & $\begin{array}{c}\text { Relapsing/refractory } \\
\text { MM }\end{array}$ & Total \\
\hline $\begin{array}{l}\text { Number of patients, n (\%) } \\
\text { Gender (female) } \\
\text { Age of sampling (median, range) }\end{array}$ & $\begin{array}{r}26(65 \%) \\
17(65.5 \%) \\
66(50-76) \\
\end{array}$ & $\begin{array}{r}14(35 \%) \\
4(28.5 \%) \\
72(65-75) \\
\end{array}$ & $\begin{array}{r}40(100 \%) \\
21(52.5 \%) \\
69(59-76) \\
\end{array}$ \\
\hline $\begin{array}{l}\text { ISS } \\
\text { I } \\
\text { II } \\
\text { III }\end{array}$ & $\begin{array}{r}5(19 \%) \\
10(38.5 \%) \\
11(42.5 \%) \\
\end{array}$ & $\begin{array}{l}1(7 \%) \\
6(43 \%) \\
7(50 \%)\end{array}$ & $\begin{array}{r}6(15 \%) \\
16(40 \%) \\
18(45 \%) \\
\end{array}$ \\
\hline $\begin{array}{l}\text { Myeloma isotype } \\
\text { IgG } \\
\text { IgA } \\
\text { Light chain only }\end{array}$ & $\begin{array}{r}18(69 \%) \\
3(11.5 \%) \\
5(19.5 \%) \\
\end{array}$ & $\begin{array}{r}9(64 \%) \\
3(21.5 \%) \\
2(14.5 \%) \\
\end{array}$ & $\begin{array}{r}27(67.5 \%) \\
6(15 \%) \\
7(17.5 \%) \\
\end{array}$ \\
\hline $\begin{array}{l}\text { Type of Ig light chain (serum) } \\
\text { Kappa } \\
\text { Lambda } \\
\text { None } \\
\end{array}$ & $\begin{array}{r}16(61.5 \%) \\
9(34.5 \%) \\
1(4 \%) \\
\end{array}$ & $\begin{array}{l}7(50 \%) \\
7(50 \%) \\
0(0 \%) \\
\end{array}$ & $\begin{array}{r}23(57.5 \%) \\
16(40 \%) \\
1(2.5 \%) \\
\end{array}$ \\
\hline Osteolytic bone lesion/s, n (\%) & $12(46 \%)$ & $10(71.5 \%)$ & $22(55 \%)$ \\
\hline $\begin{array}{l}\text { Laboratory values } \\
\beta-2 \text { microglobulin }>\mathrm{UNV} \\
\text { Creatinine } \geq 1.3 \mathrm{mg} / \mathrm{dl} \\
\mathrm{LDH}>\mathrm{UNV} \\
\text { Serum calcium }>\mathrm{UNV} \\
\text { Hemoglobin } \leq 12 \mathrm{~g} / \mathrm{dl} \\
\text { Platelets }<100,000 / \mathrm{mm}^{3}\end{array}$ & $\begin{array}{r}18(69 \%) \\
9(34.5 \%) \\
6(23 \%) \\
9(34.5 \%) \\
23(88.5 \%) \\
2(7.5 \%)\end{array}$ & $\begin{array}{r}9(64 \%) \\
4(28.5 \%) \\
2(14 \%) \\
11(78.5 \%) \\
8(57 \%) \\
1(7 \%)\end{array}$ & $\begin{array}{r}27(67.5 \%) \\
13(32.5 \%) \\
8(20 \%) \\
20(50 \%) \\
31(80 \%) \\
3(7.5 \%)\end{array}$ \\
\hline $\begin{array}{l}\text { Prior treatment } \\
\text { 1-3 therapy lines } \\
\geq 4 \text { therapy lines } \\
\text { BTZ based therapy } \\
\text { IMiD therapy } \\
\text { No therapy }\end{array}$ & $\begin{array}{r}0(0 \%) \\
0(0 \%) \\
0(0 \%) \\
0(0 \%) \\
26(100 \%)\end{array}$ & $\begin{array}{r}8(57 \%) \\
6(43 \%) \\
12(85.5 \%) \\
11(78.5 \%) \\
0(0 \%)\end{array}$ & $\begin{array}{r}8(20 \%) \\
6(15 \%) \\
12(30 \%) \\
11(27.5 \%) \\
26(65 \%)\end{array}$ \\
\hline
\end{tabular}

ISS, International Staging System; UNV, upper normal values; LDH, lactate dehydrogenases; BTZ, bortezomib; IMiD, immunomodulatory drugs

Table 2 Immune checkpoint expression (\%) in PB CD4+ T subsets in MM stages and controls (HC) 


\begin{tabular}{|c|c|c|c|c|}
\hline T-cell subset (\%) & $\begin{array}{c}\text { Stage I/II of MM } \\
(\mathrm{n}=22)\end{array}$ & $\begin{array}{c}\text { Stage III of MM } \\
\qquad(\mathrm{n}=18)\end{array}$ & $\begin{array}{c}\mathrm{HC} \\
(\mathrm{n}=20) \\
\end{array}$ & $P$-value \\
\hline $\mathrm{CD}^{+} \mathrm{CD}^{+}{ }^{+} \mathrm{PD}-1^{+}$ & $\begin{array}{r}16.8 \\
(11.68-19.86)\end{array}$ & $\begin{array}{r}14.7 \\
(12.18-18.87)\end{array}$ & $\begin{array}{r}12.54 \\
(8.37-15.29)\end{array}$ & $\begin{array}{l}\text { a) } 0.596 \\
\text { b) } 0.012 \\
\text { c) } 0.084\end{array}$ \\
\hline $\mathrm{CD}^{+}{ }^{+} \mathrm{CD} 127^{+} \mathrm{PD}-1^{+}$ & $\begin{array}{r}23.4 \\
(16.57-30.05)\end{array}$ & $\begin{array}{r}22.2 \\
(13.97-31.42)\end{array}$ & $\begin{array}{r}16.8 \\
(10.52-21.75)\end{array}$ & $\begin{array}{l}\text { a) } 0.675 \\
\text { b) } 0.023 \\
\text { c) } 0.027\end{array}$ \\
\hline $\mathrm{CD}^{+} \mathrm{CD} 127^{-\mathrm{PD}}-1^{+}$ & $\begin{array}{r}9.70 \\
(6.44-13.98)\end{array}$ & $\begin{array}{r}11.49 \\
(7.97-12.80)\end{array}$ & $\begin{array}{r}6.14 \\
(3.90-7.62)\end{array}$ & $\begin{array}{l}\text { a) } 0.975 \\
\text { b) } 0.023 \\
\text { c) } 0.027\end{array}$ \\
\hline $\mathrm{CD}^{+} \mathrm{CD}^{+} \mathrm{BTLA}^{+}$ & $\begin{array}{r}27.38 \\
(2.46-4.76)\end{array}$ & $\begin{array}{r}26.45 \\
(2.38-5.58)\end{array}$ & $\begin{array}{r}23.85 \\
(17.04-40.16)\end{array}$ & $\begin{array}{l}\text { a) } 0.999 \\
\text { b) } 0.572 \\
\text { c) } 0.751\end{array}$ \\
\hline $\mathrm{CD}^{+}{ }^{+} \mathrm{CD} 127^{+} \mathrm{BTLA}^{+}$ & $\begin{array}{r}23.30 \\
(13.29-49.21)\end{array}$ & $\begin{array}{r}24.78 \\
(15.60-51.60)\end{array}$ & $\begin{array}{r}32.50 \\
(20.75-54.43)\end{array}$ & $\begin{array}{l}\text { a) } 0.947 \\
\text { b) } 0.352 \\
\text { c) } 0.304\end{array}$ \\
\hline $\mathrm{CD}^{+}{ }^{+} \mathrm{CD} 127^{-} \mathrm{BTLA}^{+}$ & $\begin{array}{r}5.10 \\
(2.06-7.60)\end{array}$ & $\begin{array}{r}4.05 \\
(3.72-7.35)\end{array}$ & $\begin{array}{r}2.87 \\
(1.85-3.40)\end{array}$ & $\begin{array}{l}\text { a) } 0.998 \\
\text { b) } 0.619 \\
\text { c) } 0.148\end{array}$ \\
\hline $\mathrm{CD}^{+} \mathrm{CD}^{+}{ }^{+} \mathrm{CTLA}-4^{+}$ & $\begin{array}{r}1.61 \\
(1.00-2.51)\end{array}$ & $\begin{array}{r}1.17 \\
(0.55-3.04)\end{array}$ & $\begin{array}{r}1.27 \\
(0.78-2.00)\end{array}$ & $\begin{array}{l}\text { a) } 0.889 \\
\text { b) } 0.342 \\
\text { c) } 0.239\end{array}$ \\
\hline $\mathrm{CD}^{+}{ }^{+} \mathrm{CD} 127^{+} \mathrm{CTLA}^{+}$ & $\begin{array}{r}3.28 \\
(2.21-6.00)\end{array}$ & $\begin{array}{r}3.84 \\
(1.47-6.07)\end{array}$ & $\begin{array}{r}3.55 \\
(1.64-4.22)\end{array}$ & $\begin{array}{l}\text { a) } 0.999 \\
\text { b) } 0.628 \\
\text { c) } 0.721\end{array}$ \\
\hline $\mathrm{CD}^{+}{ }^{+} \mathrm{CD} 127^{-} \mathrm{CTLA}^{+}$ & $\begin{array}{r}1.57 \\
(0.75-2.20)\end{array}$ & $\begin{array}{r}1.99 \\
(0.88-2.49)\end{array}$ & $\begin{array}{r}1.14 \\
(0.56-1.37)\end{array}$ & $\begin{array}{l}\text { a) } 0.972 \\
\text { b) } 0.398 \\
\text { c) } 0.290\end{array}$ \\
\hline $\mathrm{CD}^{+} \mathrm{CD}^{+}{ }^{+} \mathrm{CD} 69^{+}$ & $\begin{array}{r}0.56 \\
(0.22-0.83)\end{array}$ & $\begin{array}{r}0.94 \\
(0.35-1.21)\end{array}$ & $\begin{array}{r}0.42 \\
(0.23-0.44)\end{array}$ & $\begin{array}{l}\text { a) } 0.076 \\
\text { b) } 0.171 \\
\text { c) } 0.006\end{array}$ \\
\hline
\end{tabular}

1. Stage I/II vs. stage III

2. Stage I/II vs. HC

3. Stage III vs. HC 
Differences in the proportions of PD-1, BTLA, and CTLA-4-expressing CD4+ T cells between examined groups were evaluated using nonparametric tests (Kruskal-Wallis and Mann-Whitney U-test).

Table 3 Immune checkpoint expression (MFI) in PB CD4+ T subsets in MM patients and controls (HC)

\begin{tabular}{|c|c|c|c|}
\hline $\begin{array}{c}\text { Receptor } \\
\text { in } \mathrm{T} \text { cell subsets }\end{array}$ & $\begin{array}{l}\text { MM patients } \\
(n=40)\end{array}$ & $\begin{array}{c}\mathrm{HC} \\
(\mathrm{n}=20)\end{array}$ & $P$-value \\
\hline $\begin{array}{l}\text { PD-1 } \\
\text { in CD4 }\end{array}$ & $\begin{array}{r}76.87 \\
(58.84-94.85) \\
\end{array}$ & $\begin{array}{r}83.04 \\
(71.73-105.09) \\
\end{array}$ & 0.191 \\
\hline $\begin{array}{l}\text { PD-1 } \\
\text { in CD4 }{ }^{+} \mathrm{CD} 127^{+}\end{array}$ & $\begin{array}{r}69.14 \\
(56.00-96.73) \\
\end{array}$ & $\begin{array}{r}90.27 \\
(60.37-105.83) \\
\end{array}$ & 0.156 \\
\hline $\begin{array}{l}\text { PD-1 } \\
\text { in CD4 }{ }^{+} \text {CD127- }\end{array}$ & $\begin{array}{r}68.47 \\
(56.93-96.25) \\
\end{array}$ & $\begin{array}{r}102.12 \\
(79.79-127.26) \\
\end{array}$ & 0.027 \\
\hline $\begin{array}{l}\text { BTLA } \\
\text { in } \mathrm{CD}^{+}\end{array}$ & $\begin{array}{r}349.49 \\
(287.06-431.90) \\
\end{array}$ & $\begin{array}{r}517.21 \\
(322.83-620.55) \\
\end{array}$ & 0.007 \\
\hline $\begin{array}{l}\text { BTLA } \\
\text { in } \mathrm{CD}^{+}{ }^{+} \mathrm{CD} 127^{+}\end{array}$ & $\begin{array}{r}286.19 \\
(257.35-396.75)\end{array}$ & $\begin{array}{r}417.93 \\
(378.79-496.87)\end{array}$ & 0.053 \\
\hline $\begin{array}{l}\text { BTLA } \\
\text { in CD4 }{ }^{+} \text {CD } 127^{-}\end{array}$ & $\begin{array}{r}341.99 \\
(267.35-738.00) \\
\end{array}$ & $\begin{array}{r}465.34 \\
(401.35-611.63) \\
\end{array}$ & 0.321 \\
\hline $\begin{array}{l}\text { CTLA-4 } \\
\text { in CD4 }{ }^{+} \mathrm{T} \text { cells }\end{array}$ & $\begin{array}{r}61.82 \\
(43.11-79.70) \\
\end{array}$ & $\begin{array}{r}65.40 \\
(60.10-111.23) \\
\end{array}$ & 0.181 \\
\hline $\begin{array}{l}\text { CTLA-4 } \\
\text { in CD } 4^{+} \mathrm{CD} 127^{+}\end{array}$ & $\begin{array}{r}41.87 \\
(33.59-51.28)\end{array}$ & $\begin{array}{r}80.95 \\
(51.92-90.07)\end{array}$ & 0.013 \\
\hline $\begin{array}{l}\text { CTLA-4 } \\
\text { in CD4 }{ }^{+} \text {CD127- } \\
\end{array}$ & $\begin{array}{r}39.34 \\
(31.75-55.66) \\
\end{array}$ & $\begin{array}{r}62.97 \\
(41.03-74.54) \\
\end{array}$ & 0.012 \\
\hline $\begin{array}{l}\text { CD69 } \\
\text { in CD4 }\end{array}$ & $\begin{array}{r}56.64 \\
(48.70-86.81)\end{array}$ & $\begin{array}{r}70.80 \\
(55.50-123.46)\end{array}$ & 0.075 \\
\hline
\end{tabular}

Differences in the fluorescence intensity of inhibitory receptors in CD4+ T cell subsets between MM patients and HC were analyzed by Mann-Whitney U-test.

Table 4 Immune checkpoint expression (MFI) in PB CD4+ T subsets in MM stages and controls (HC) 


\begin{tabular}{|c|c|c|c|c|}
\hline $\begin{array}{c}\text { Receptor } \\
\text { in } \mathrm{T} \text { cell subsets }\end{array}$ & $\begin{array}{c}\text { Stage I/II of MM } \\
(\mathrm{n}=22)\end{array}$ & $\begin{array}{c}\text { Stage III of MM } \\
\qquad(\mathrm{n}=18)\end{array}$ & $\begin{array}{c}\mathrm{HC} \\
(\mathrm{n}=20) \\
\end{array}$ & $P$-value \\
\hline $\begin{array}{l}\text { PD-1 } \\
\text { in CD4 }\end{array}$ & $\begin{array}{r}68.56 \\
(58.49-88.31)\end{array}$ & $\begin{array}{r}80.30 \\
(65.57-99.97)\end{array}$ & $\begin{array}{r}83.0 \\
(71.73-105.09)\end{array}$ & $\begin{array}{l}\text { a) } 0.528 \\
\text { b) } 0.452 \\
\text { c) } 0.996\end{array}$ \\
\hline $\begin{array}{l}\text { PD-1 } \\
\text { in CD4 }{ }^{+} \mathrm{CD} 127^{+}\end{array}$ & $\begin{array}{r}58.56 \\
(48.49-84.45)\end{array}$ & $\begin{array}{r}84.9 \\
(64.38-103.67)\end{array}$ & $\begin{array}{r}92.1 \\
(79.79-127.26)\end{array}$ & $\begin{array}{l}\text { a) } 0.447 \\
\text { b) } 0.350 \\
\text { c) } 0.999\end{array}$ \\
\hline $\begin{array}{l}\text { PD-1 } \\
\text { in CD4 }{ }^{+} \mathrm{CD} 127^{-}\end{array}$ & $\begin{array}{r}59.49 \\
(53.62-85.70)\end{array}$ & $\begin{array}{r}96.6 \\
(69.06-113.75)\end{array}$ & $\begin{array}{r}90.2 \\
(60.37-105.83)\end{array}$ & $\begin{array}{l}\text { a) } 0.007 \\
\text { b) } 0.005 \\
\text { c) } 0.870\end{array}$ \\
\hline $\begin{array}{l}\text { BTLA } \\
\text { in CD4 } 4^{+}\end{array}$ & $\begin{array}{r}350.98 \\
(287.06-442.42)\end{array}$ & $\begin{array}{r}346.10 \\
(286.20-410.52)\end{array}$ & $\begin{array}{r}517.21 \\
(322.83-620.55)\end{array}$ & $\begin{array}{l}\text { a) } 0.997 \\
\text { b) } 0.017 \\
\text { c) } 0.027\end{array}$ \\
\hline $\begin{array}{l}\text { BTLA } \\
\text { in } \mathrm{CD} 4^{+} \mathrm{CD} 127^{+}\end{array}$ & $\begin{array}{r}309.97 \\
(257.38-475.97)\end{array}$ & $\begin{array}{r}278.07 \\
(250.06-348.11)\end{array}$ & $\begin{array}{r}465.34 \\
(401.35-611.63)\end{array}$ & $\begin{array}{l}\text { a) } 0.696 \\
\text { b) } 0.996 \\
\text { c) } 0.670\end{array}$ \\
\hline $\begin{array}{l}\text { BTLA } \\
\text { in CD4 }{ }^{+} \text {CD } 127^{-}\end{array}$ & $\begin{array}{r}341.99 \\
(283.87-1045.11)\end{array}$ & $\begin{array}{r}318.24 \\
(247.64-552.38)\end{array}$ & $\begin{array}{r}417.93 \\
(378.79-496.87)\end{array}$ & $\begin{array}{l}\text { a) } 0.601 \\
\text { b) } 0.831 \\
\text { c) } 0.900\end{array}$ \\
\hline $\begin{array}{l}\text { CTLA-4 } \\
\text { in } \mathrm{CD}^{+}\end{array}$ & $\begin{array}{r}61.53 \\
(42.54-84.29)\end{array}$ & $\begin{array}{r}63.09 \\
(44.42-79.70)\end{array}$ & $\begin{array}{r}65.40 \\
(60.10-111.23)\end{array}$ & $\begin{array}{l}\text { a) } 0.724 \\
\text { b) } 0.918 \\
\text { c) } 0.501\end{array}$ \\
\hline $\begin{array}{l}\text { CTLA-4 } \\
\text { in } \mathrm{CD}^{+}{ }^{+} \mathrm{CD} 127^{+}\end{array}$ & $\begin{array}{r}40.70 \\
(33.45-70.86)\end{array}$ & $\begin{array}{r}42.19 \\
(35.42-49.59)\end{array}$ & $\begin{array}{r}62.97 \\
(41.03-74.54)\end{array}$ & $\begin{array}{l}\text { a) } 0.502 \\
\text { b) } 0.060 \\
\text { c) } 0.012\end{array}$ \\
\hline $\begin{array}{l}\text { CTLA-4 } \\
\text { in CD4 }{ }^{+} \mathrm{CD} 17^{-}\end{array}$ & $\begin{array}{r}35.20 \\
(31.75-60.31)\end{array}$ & $\begin{array}{r}40.16 \\
(35.49-50.64)\end{array}$ & $\begin{array}{r}80.95 \\
(51.92-90.07)\end{array}$ & $\begin{array}{l}\text { a) } 0.899 \\
\text { b) } 0.026 \\
\text { c) } 0.069\end{array}$ \\
\hline $\begin{array}{l}\text { CD69 } \\
\text { in CD4 }\end{array}$ & $\begin{array}{r}58.82 \\
(47.87-98.47)\end{array}$ & $\begin{array}{r}53.80 \\
(49.92-70.93)\end{array}$ & $\begin{array}{r}70.80 \\
(55.50-123.46)\end{array}$ & $\begin{array}{l}\text { a) } 0.846 \\
\text { b) } 0.105 \\
\text { c) } 0.067\end{array}$ \\
\hline
\end{tabular}

1. Stage I/II vs. stage III

2. Stage I/II vs. HC

3. Stage III vs. HC 
Differences in fluorescence intensity of immune checkpoints between examined groups were evaluated using nonparametric tests (Kruskal-Wallis and Mann-Whitney U-test).

Table 5 Frequency of circulating Th1, Th17, and Treg cells in MM stages and controls (HC)

\begin{tabular}{|c|c|c|c|c|}
\hline T-cell subset (\%) & $\begin{array}{c}\text { Stage I/II of MM } \\
(\mathrm{n}=22)\end{array}$ & $\begin{array}{c}\text { Stage III of MM } \\
(\mathrm{n}=18)\end{array}$ & $\begin{array}{c}\mathrm{HC} \\
(\mathrm{n}=20)\end{array}$ & $P$-value \\
\hline $\mathrm{CD}^{2}{ }^{-\mathrm{CD}} 183^{+} \mathrm{IFN}^{-} \gamma^{+}$ & $\begin{array}{r}3.04 \\
(2.04-6.52)\end{array}$ & $\begin{array}{r}3.49 \\
(2.36-5.62)\end{array}$ & $\begin{array}{r}8.77 \\
(5.13-9.71)\end{array}$ & $\begin{array}{l}\text { a) } 0.678 \\
\text { b) } 0.015 \\
\text { c) } 0.005\end{array}$ \\
\hline $\mathrm{CD}^{+}{ }^{\mathrm{CD}} 8^{-} \mathrm{IFN}^{-} \gamma^{+}$ & $\begin{array}{r}5.38 \\
(3.36-7.02)\end{array}$ & $\begin{array}{r}3.56 \\
(2.74-6.40)\end{array}$ & $\begin{array}{r}9.00 \\
(7.66-10.07)\end{array}$ & $\begin{array}{l}\text { a) } 0.220 \\
\text { b) } 0.003 \\
\text { c) } 0.002\end{array}$ \\
\hline $\mathrm{CD} 194^{+} \mathrm{CD} 196^{+} \mathrm{IL}^{-17^{+}}$ & $\begin{array}{r}0.55 \\
(0.28-0.81)\end{array}$ & $\begin{array}{r}0.57 \\
(0.31-0.89)\end{array}$ & $\begin{array}{r}0.36 \\
(0.26-0.45)\end{array}$ & $\begin{array}{l}\text { a) } 0.737 \\
\text { b) } 0.023 \\
\text { c) } 0.037\end{array}$ \\
\hline $\mathrm{CD}^{+}{ }^{+} \mathrm{CD} 8{ }^{-I L}-17^{+}$ & $\begin{array}{r}0.52 \\
(0.28-0.78)\end{array}$ & $\begin{array}{r}0.50 \\
(0.23-0.58)\end{array}$ & $\begin{array}{r}0.32 \\
(0.22-0.45)\end{array}$ & $\begin{array}{l}\text { a) } 0.589 \\
\text { b) } 0.023 \\
\text { c) } 0.070\end{array}$ \\
\hline $\mathrm{CD}^{+}{ }^{+} \mathrm{CD} 25^{+} \mathrm{CD} 127^{-}$ & $\begin{array}{r}5.96 \\
(4.81-7.95)\end{array}$ & $\begin{array}{r}5.16 \\
(3.51-6.99)\end{array}$ & $\begin{array}{r}3.69 \\
(2.72-3.90)\end{array}$ & $\begin{array}{r}\text { a) } 0.150 \\
\text { b) }<0.001 \\
\text { c) } 0.004\end{array}$ \\
\hline $\mathrm{CD}^{+}{ }^{+} \mathrm{CD} 25^{\mathrm{hi}} \mathrm{CD} 127-$ & $\begin{array}{r}0.88 \\
(0.64-1.83)\end{array}$ & $\begin{array}{r}1.19 \\
(0.77-2.13)\end{array}$ & $\begin{array}{r}0.54 \\
(0.39-0.67)\end{array}$ & $\begin{array}{r}\text { a) } 0.154 \\
\text { b) }<0.001 \\
\text { c) } 0.002\end{array}$ \\
\hline $\mathrm{CD}^{+}{ }^{+} \mathrm{CD}_{25}{ }^{+} \mathrm{FOXP}^{+}$ & $\begin{array}{r}4.80 \\
(3.77-5.95)\end{array}$ & $\begin{array}{r}4.07 \\
(3.34-5.12)\end{array}$ & $\begin{array}{r}2.51 \\
(1.66-3.19)\end{array}$ & $\begin{array}{r}\text { a) } 0.021 \\
\text { b) }<0.001 \\
\text { c) } 0.001\end{array}$ \\
\hline $\mathrm{CD}^{+}{ }^{+} \mathrm{CD}^{2} 5^{\mathrm{hi}} \mathrm{FOXP}^{+}$ & $\begin{array}{r}0.60 \\
(0.43-0.80)\end{array}$ & $\begin{array}{r}0.74 \\
(0.44-0.96)\end{array}$ & $\begin{array}{r}0.54 \\
(0.24-0.61)\end{array}$ & $\begin{array}{l}\text { a) } 0.464 \\
\text { b) } 0.120 \\
\text { c) } 0.021\end{array}$ \\
\hline $\mathrm{CD}^{+} \mathrm{FOXP}^{+} \mathrm{CD}^{2} 7^{-}$ & $\begin{array}{r}4.91 \\
(4.52-7.02)\end{array}$ & $\begin{array}{r}3.67 \\
(3.07-4.47)\end{array}$ & $\begin{array}{r}2.34 \\
(1.49-2.67)\end{array}$ & $\begin{array}{r}\text { a) } 0.021 \\
\text { b) }<0.001 \\
\text { c) } 0.001\end{array}$ \\
\hline
\end{tabular}

1. Stage I/II vs. stage III 
2. Stage I/II vs. HC

3. Stage III vs. HC

Differences in Th1, Th17, and Treg cell subsets between examined groups were evaluated using nonparametric tests (Kruskal-Wallis and Mann-Whitney U-test).

Table 6 Treg subsets (\%) in PB of MM patients and healthy controls (HC)

\begin{tabular}{|c|c|c|c|}
\hline Treg cell subset (\%) & $\begin{array}{c}\text { MM } \\
(n=40)\end{array}$ & $\begin{array}{c}\mathrm{HC} \\
(\mathrm{n}=20)\end{array}$ & $P$-value \\
\hline $\mathrm{CD}^{+}{ }^{+} \mathrm{CD} 25^{+} \mathrm{CD} 127^{-}$ & $\begin{array}{r}5.70 \\
(4.40-7.93) \\
\end{array}$ & $\begin{array}{r}3.69 \\
(2.72-3.90) \\
\end{array}$ & $<0.001$ \\
\hline $\mathrm{CD}^{+}{ }^{+} \mathrm{CD} 25^{\mathrm{hi}} \mathrm{CD} 127-$ & $\begin{array}{r}1.05 \\
(0.65-1.85) \\
\end{array}$ & $\begin{array}{r}0.54 \\
(0.39-0.67) \\
\end{array}$ & $<0.001$ \\
\hline $\mathrm{CD}^{+}{ }^{+} \mathrm{CD}_{25}{ }^{+} \mathrm{FOXP}^{+}$ & $\begin{array}{r}4.30 \\
(3.43-5.60) \\
\end{array}$ & $\begin{array}{r}2.51 \\
(1.66-3.19) \\
\end{array}$ & $<0.001$ \\
\hline $\mathrm{CD}^{+}{ }^{+} \mathrm{CD} 25^{\mathrm{hi}} \mathrm{FOXP}^{+}$ & $\begin{array}{r}0.66 \\
(0.43-0.87) \\
\end{array}$ & $\begin{array}{r}0.54 \\
(0.24-0.61) \\
\end{array}$ & 0.021 \\
\hline $\mathrm{CD}^{+}{ }^{+} \mathrm{FOXP}^{+} \mathrm{CD}^{2} 7^{-}$ & $\begin{array}{r}4.52 \\
(3.67-5.35) \\
\end{array}$ & $\begin{array}{r}2.34 \\
(1.49-2.67) \\
\end{array}$ & $<0.001$ \\
\hline
\end{tabular}

Differences in the abundance of Treg subsets between MM patients and HC were analyzed by MannWhitney U-test.

\section{Figures}


a

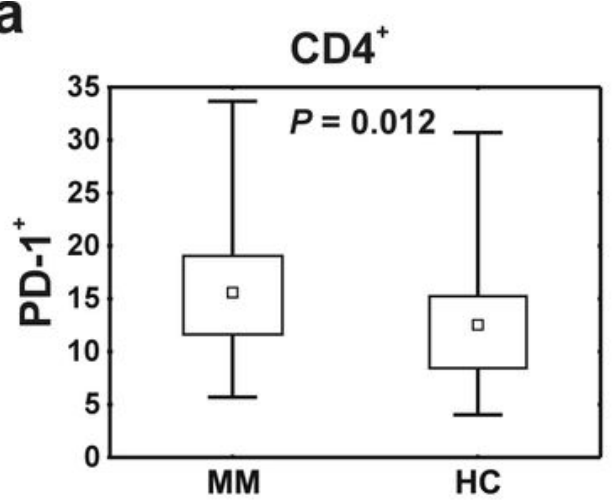

$\mathrm{CD}^{+} \mathrm{CD} 127^{+}$

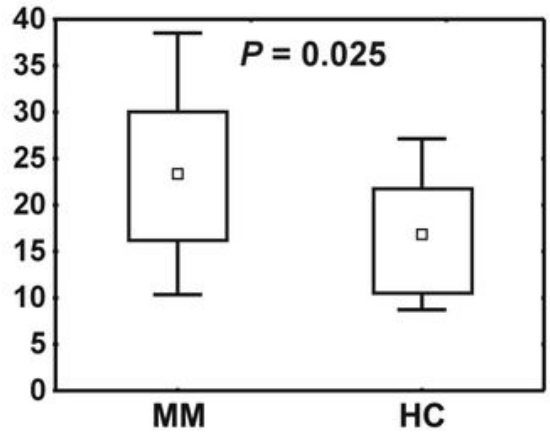

$\mathrm{CD}^{+} \mathrm{CD} 127^{+}$

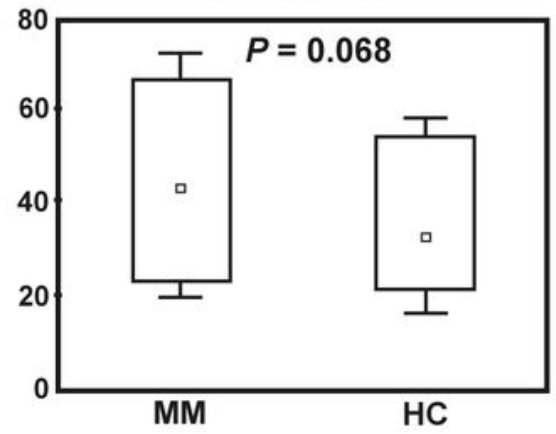

$\mathrm{CD}^{+} \mathrm{CD} 127^{+}$

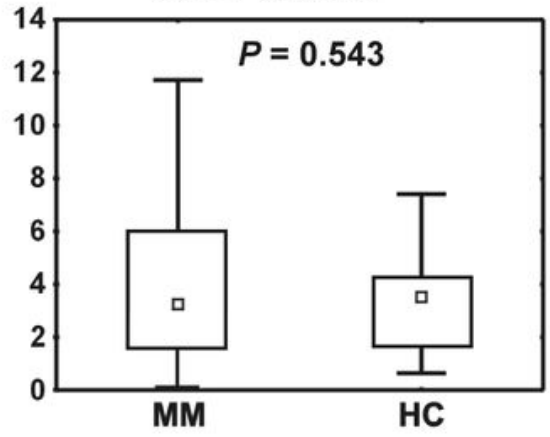

$\mathrm{CD}^{+} \mathrm{CD} 127$

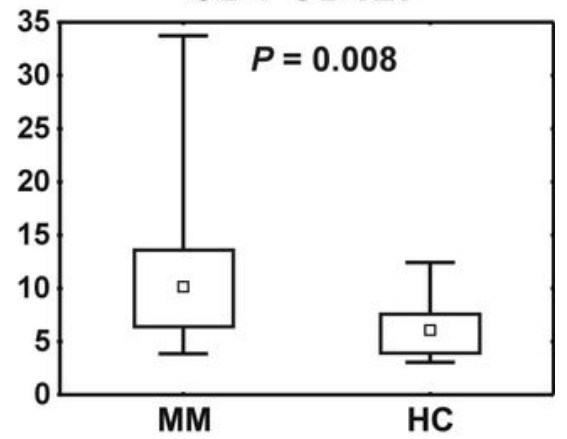

$\mathrm{CD}^{+} \mathrm{CD} 127^{-}$

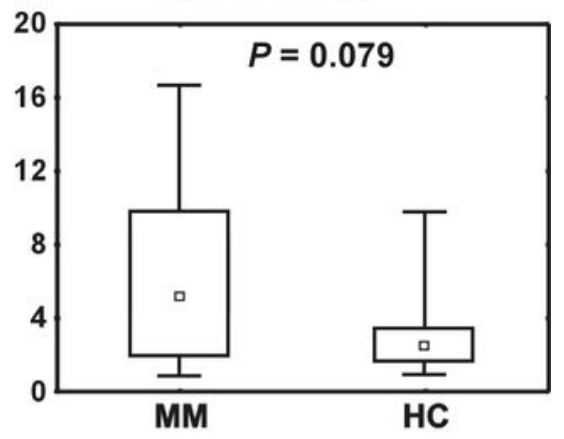

$\mathrm{CD}^{+} \mathrm{CD} 127^{-}$

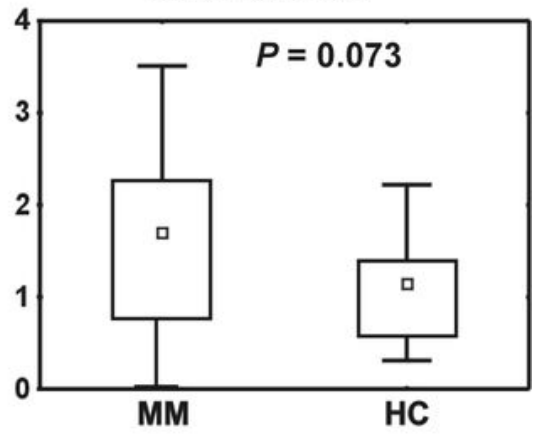

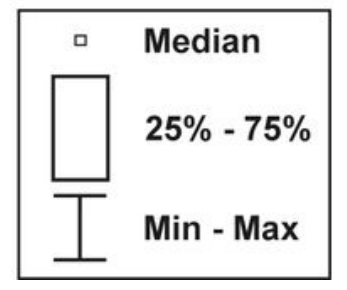

Figure 1

Distribution of immune checkpoints in different PB CD4+ T cell subsets. (a) Among studied inhibitors, significant differences between myeloma patients $(\mathrm{MM})$ and healthy controls (HC) were found in PD-1 expression only $(P<0.05)$. The frequency of BTLA+ $(b)$ and CTLA-4+ $(c)$ cells did not significantly differ between MM and HC ( $\mathrm{p}>0.05)$. For statistical analysis the Mann-Whitney U-test was used. 
a

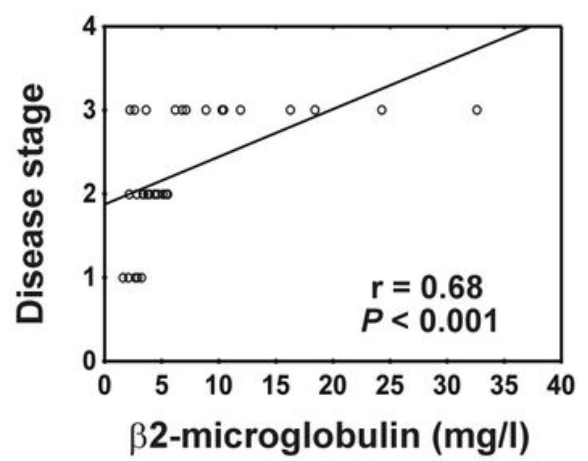

C

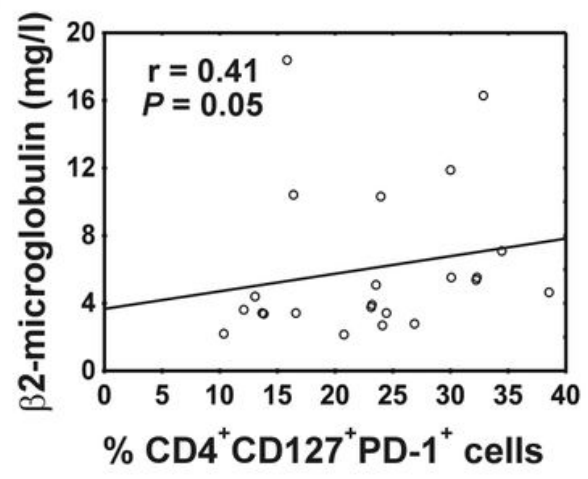

f

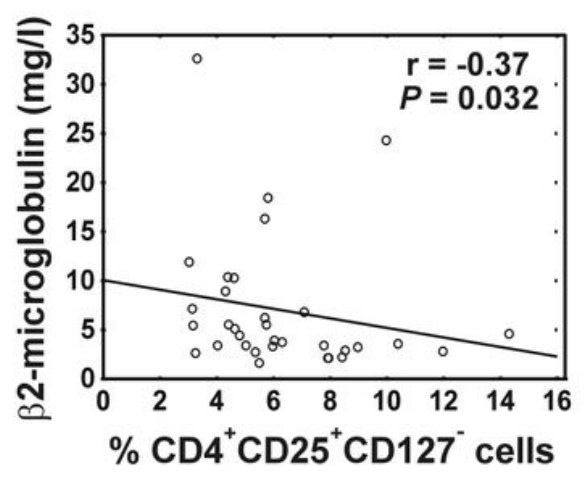

b

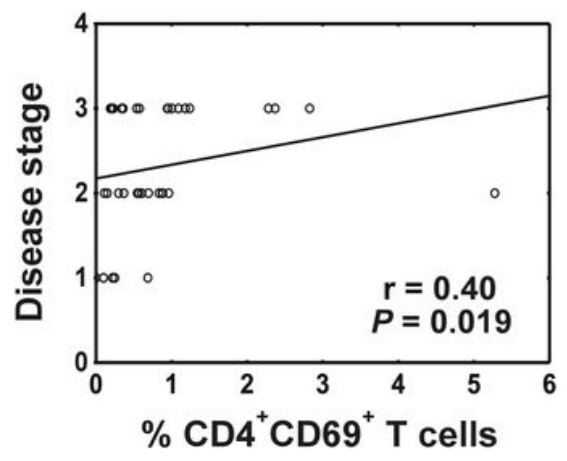

d

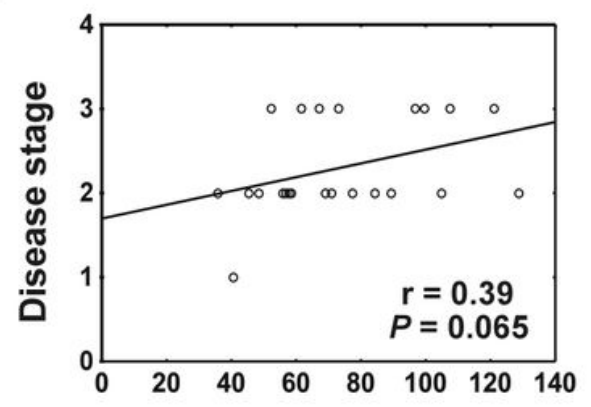

$\mathrm{PD}-1$ intensity in $\mathrm{CD}^{+} \mathrm{CD} 127^{+}$cells

g

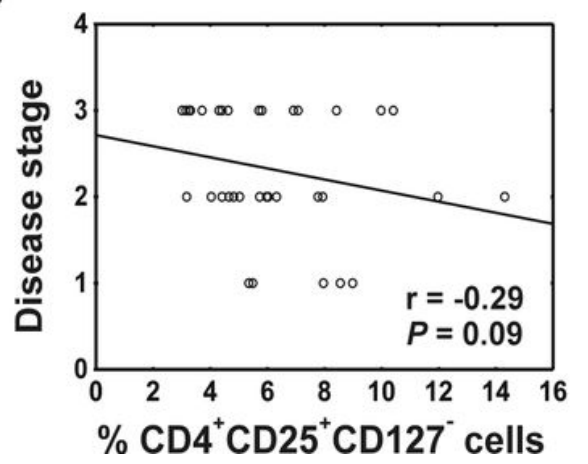

e

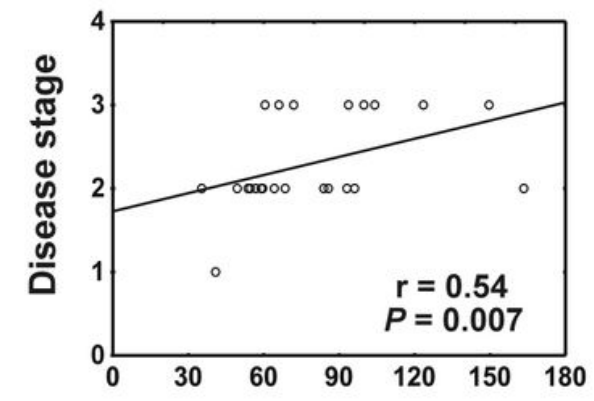

$\mathrm{PD}-1$ intensity in $\mathrm{CD}^{+}{ }^{+} \mathrm{CD} 127^{-}$cells

h

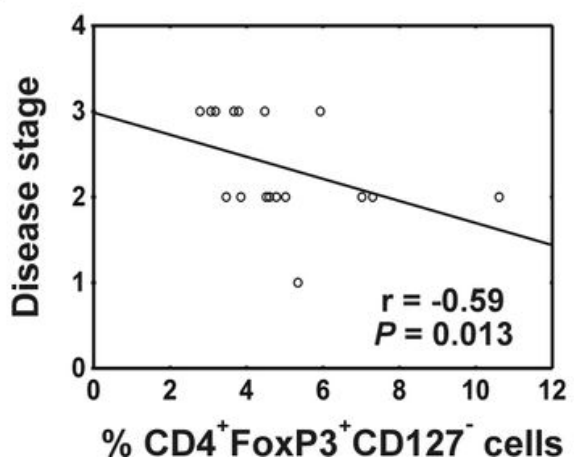

Figure 2

Correlation of CD69, PD-1, and Treg with myeloma stage. We confirmed a strong association of tumor stage with serum level of $\beta 2$-microglobulin $(p<0.001)(a)$, both of which also correlate with CD69 $(p=$ $0.019)(b)$, PD-1 ( $p \leq 0.06)(c-e)$, and some Treg subsets $(p<0.09)(f-h)$. Correlation was analyzed using the Spearman rank correlation coefficient. 

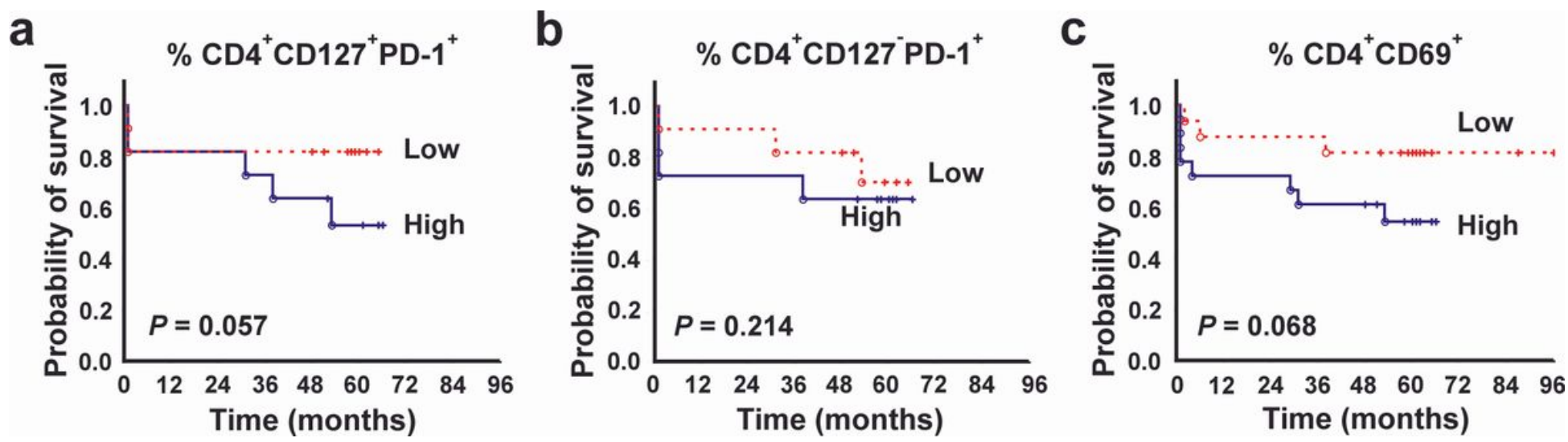

Figure 3

Effect of peripheral PD-1+ or CD69+ CD4+ T cell frequency on patient survival. We divided our cohort of patients into high and low expressors of each studied antigen according to median split. Survival of both groups was then compared with a log-rank test showing some impact of both PD-1 abundance within Teff $(C D 4+C D 127+T$ cells, $p=0.05)$ and activated phenotype of CD4+ T cells $(p=0.06)$ on patient survival. 

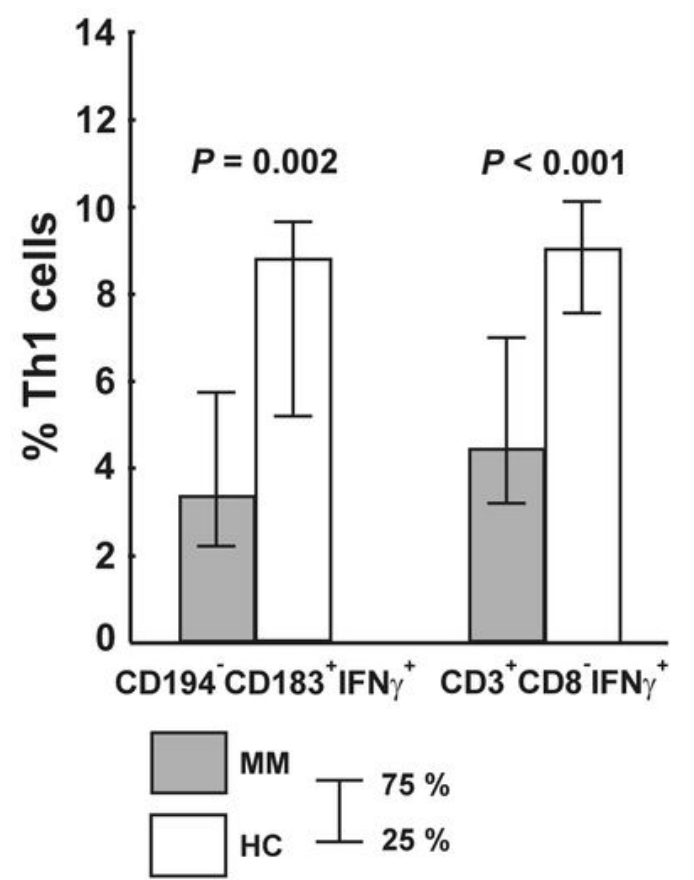
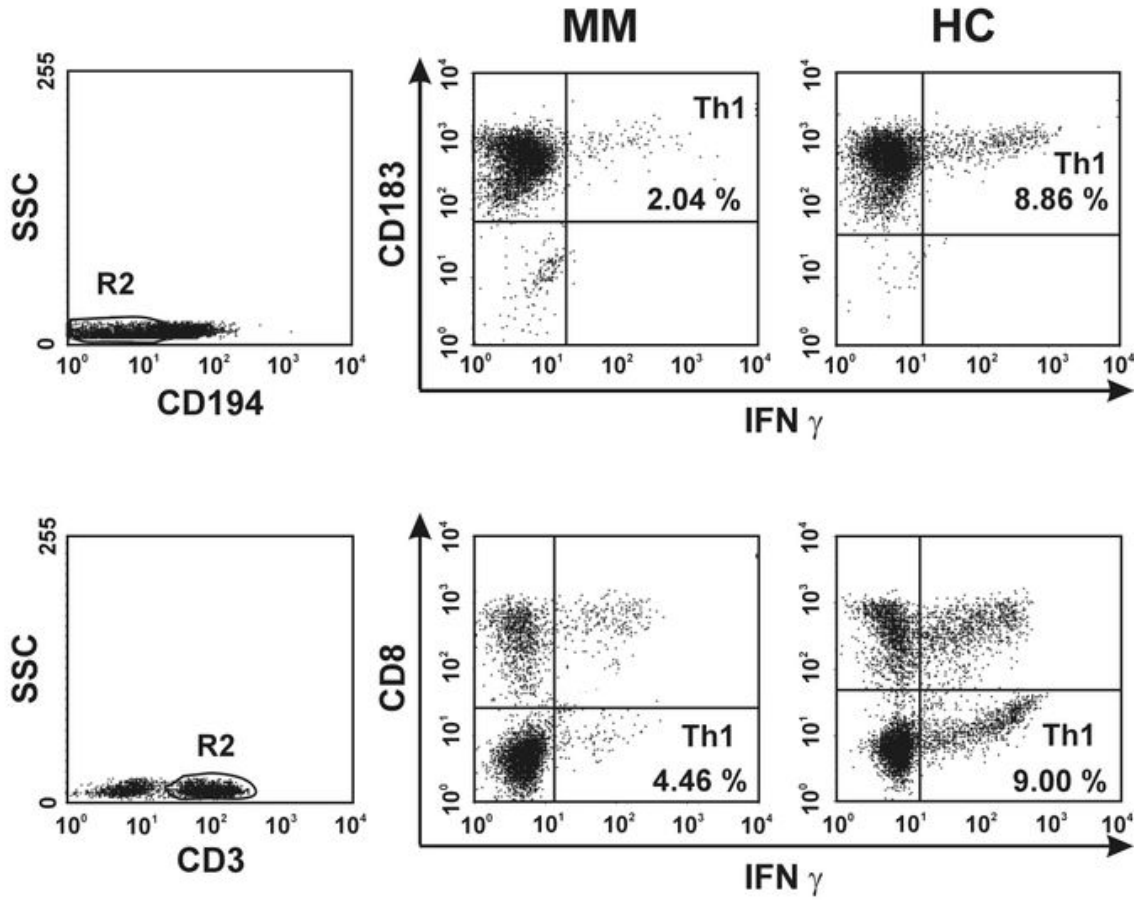

IFN $\gamma$

b

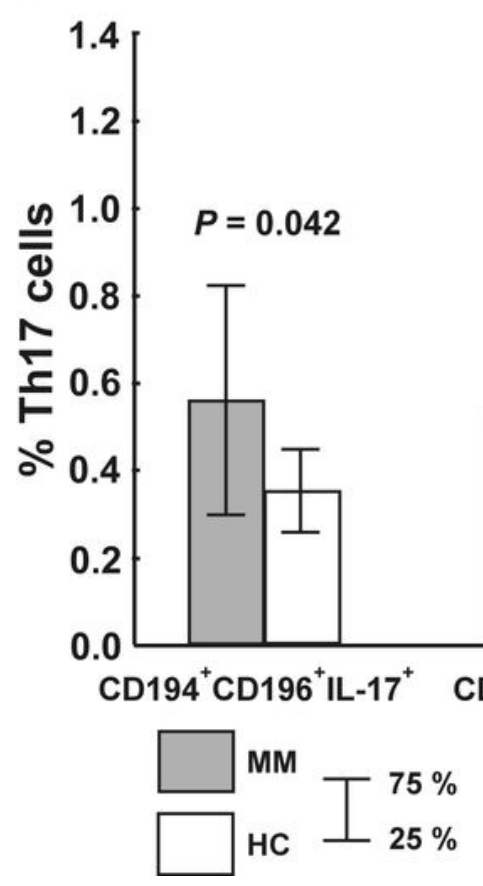

MM
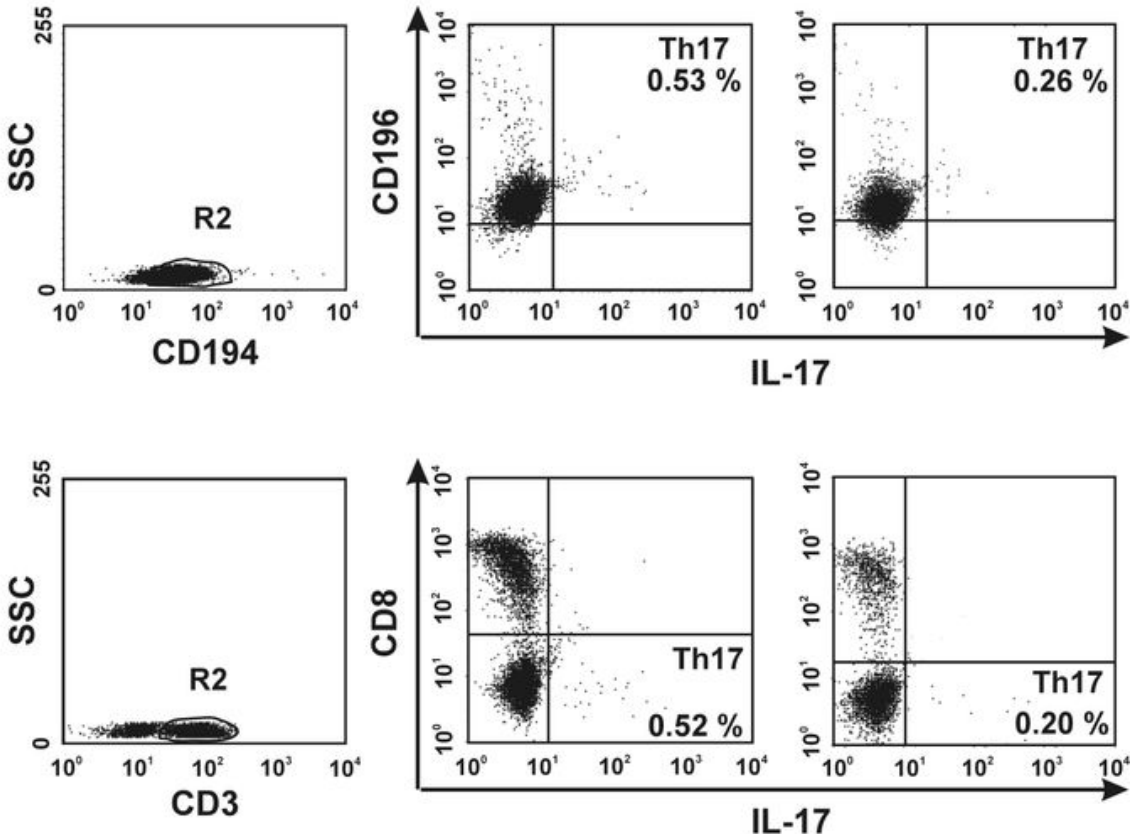

HC

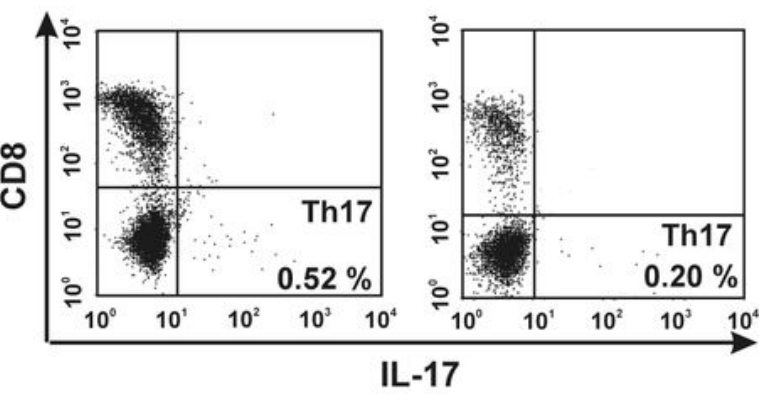

Figure 4

Peripheral distribution of Th1 and Th17 cells. Th1 cells were phenotyped by flow cytometry as CD194CD183+IFN+ and CD3+CD8-IFN+ cells. Th17 cells were identified as CD194+CD196+IL-17+ and CD3+CD8-IL-17+ cells. Peripheral blood mononuclear cells (PBMCs) were gated on FSC/SSC profile (R1); then CD3+ and CD194 - or CD194+ cells were gated (R2) for Th1 or Th17 cells assessment, respectively. Numbers on dot plots represent the percentage of Th1 (a) or Th17 (b) cells within PBMCs in MM patients 
and healthy subjects $(\mathrm{HC})$. Significant decrease in PB Th1 and increase in Th17 cells within patients $(\mathrm{p}=$ 0.05) were shown in all analyses using the Mann-Whitney U-test.

a

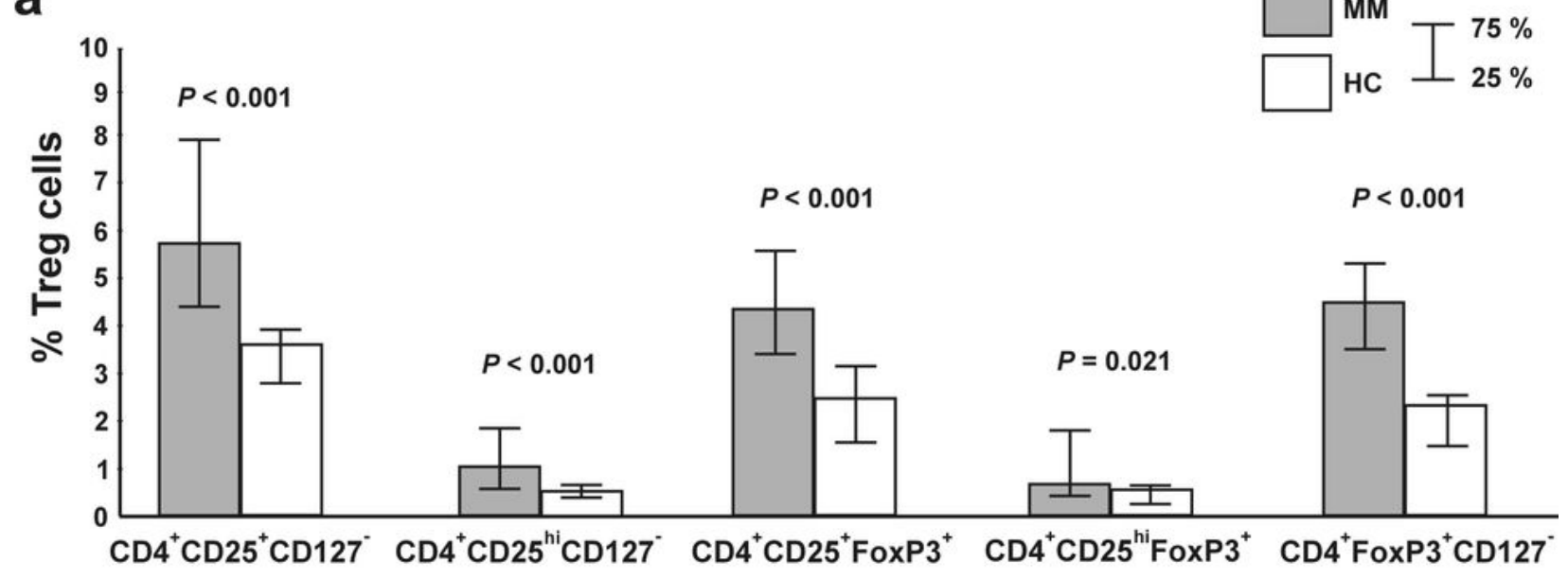

b
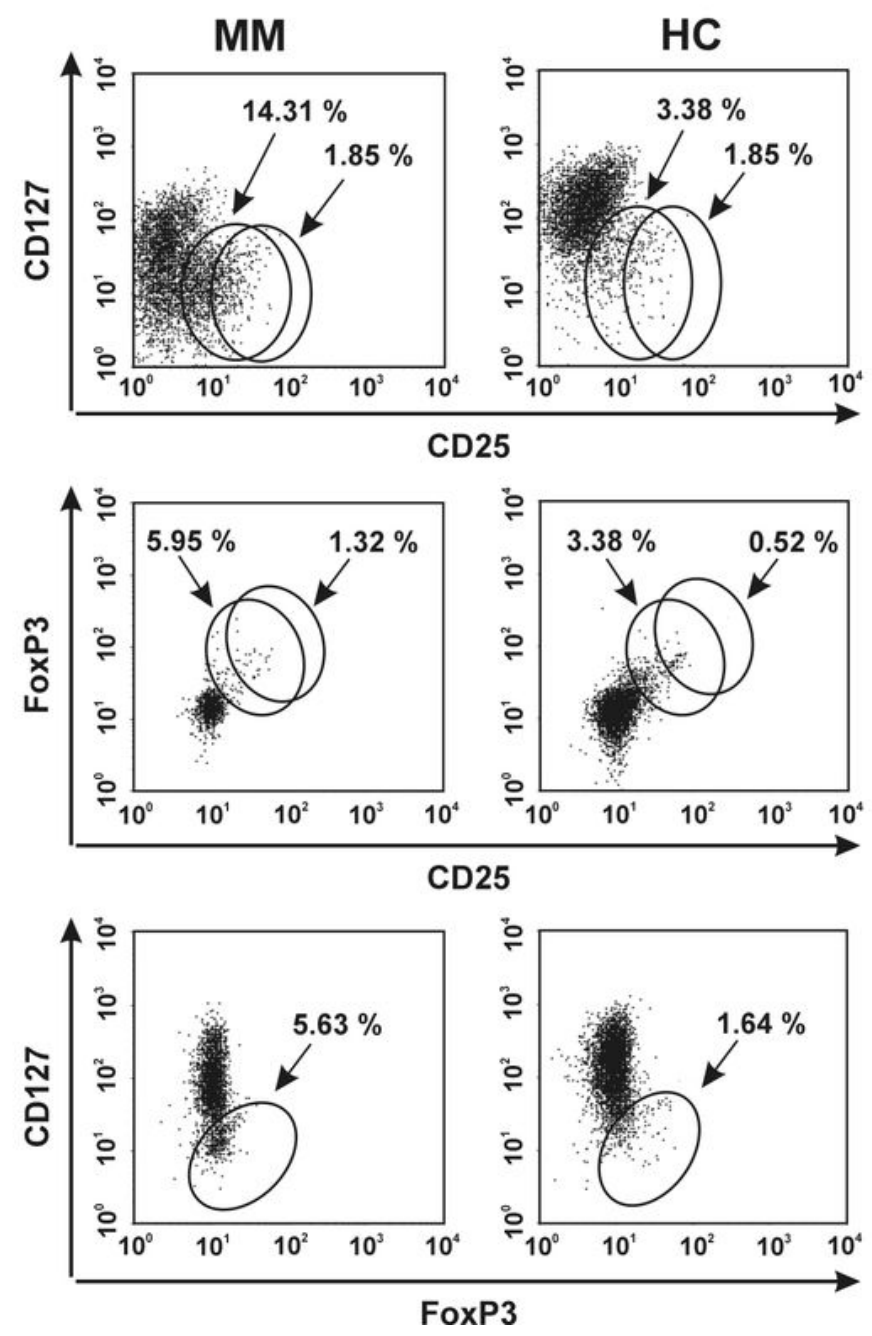

Figure 5

Frequency values of Treg subsets in PB. Treg cells were identified in fluorocytometric analysis as the following subsets: CD4+CD25+CD127-, CD4+CD25hiCD127-, CD4+CD25+FOXP3+, CD4+CD25hiFOXP3+, and CD4+FOXP3+CD127- cells. PBMCs were gated on FSC/SSC profile (R1); then, certain subpopulations 
of Tregs were assessed within CD4+ T cells gated on SSC/CD4 (R2). a We found significantly increased Treg cells in MM patients regarding all examined subsets $(p<0.05)$. b Examples of dot plots from cytometric analyses showing the proportion of Tregs in patients and healthy controls $(\mathrm{HC})$. For statistical analysis the Mann-Whitney U-test was used.

\section{Supplementary Files}

This is a list of supplementary files associated with this preprint. Click to download.

- supplement4.tif

- supplement1.tif

- supplement2.tif

- supplement3.tif 